\title{
Hypoxia in the Holocene Baltic Sea : Comparing modern versus past intervals using sedimentary trace metals
}

van Helmond, Niels A. G. M.

2018-08-20

van Helmond, N A G M , Jilbert , T \& Slomp , C P 2018 , ' Hypoxia in the Holocene Baltic Sea : Comparing modern versus past intervals using sedimentary trace metals ' , Chemical Geology , vol. 493 , pp. 478-490 . https://doi.org/10.1016/j.chemgeo.2018.06.028

http://hdl.handle.net/10138/318417

https://doi.org/10.1016/j.chemgeo.2018.06.028

cc_by_nc_nd

acceptedVersion

Downloaded from Helda, University of Helsinki institutional repository.

This is an electronic reprint of the original article.

This reprint may differ from the original in pagination and typographic detail.

Please cite the original version. 
1 Hypoxia in the Holocene Baltic Sea: comparing modern versus past intervals

4 Niels A.G.M. van Helmond ${ }^{\mathrm{a}^{*}}$, Tom Jilbert ${ }^{\mathrm{a}, \mathrm{b}}$ and Caroline P. Slomp ${ }^{\mathrm{a}}$

5

$6 \quad *$ Corresponding author: E-mail: $\underline{\text { n.vanhelmond@uu.nl }}$

7

8

9

\section{using sedimentary trace metals}

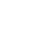
van Helmond), c.p.slomp@uu.nl (Caroline P. Slomp) Environmental Sciences, University of Helsinki, Finland; tom.jilbert@ helsinki.fi

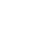

\section{Highlights (max. 5 - max. 125 characters each)} 6 metals. 8 that modern oxygen depletion is most intense. of the present-day water column Mo inventory. further enriched under more reducing conditions. 5

a Department of Earth Sciences, Faculty of Geosciences, Utrecht University. Princetonlaan 8a, 3584 CB Utrecht, Netherlands; n.vanhelmond@uu.nl (Niels A.G.M.

b Ecosystems and Environment Research Program, Faculty of Biological and

5 - Holocene Baltic Sea sediments from hypoxic intervals are enriched in trace

- The strongest enrichments in $U$ are observed in recent sediments, indicating

9 - Lower Mo in recent sediments compared with $\mathrm{C}_{\text {org }}$ and $\mathrm{U}$, suggests depletion

1 - Enrichment of Re commences under mildly reducing conditions, but Re is not
- $\mathrm{Ni}, \mathrm{Tl}$ and $\mathrm{Cu}$ correlate with $\mathrm{C}_{\text {org }}$, while $\mathrm{Pb}, \mathrm{Zn}, \mathrm{As}, \mathrm{Sb}$ and $\mathrm{Cd}$ are all strongly influenced by anthropogenic pollution.




\section{Abstract}

Anthropogenic nutrient input has caused a rapid expansion of bottom water hypoxia in the Baltic Sea over the past century. Two earlier intervals of widespread hypoxia, coinciding with the Holocene Thermal Maximum $\left(\mathrm{HTM}_{\mathrm{HI}} ; 8-4\right.$ ka before present; BP) and the Medieval Climate Anomaly $\left(\mathrm{MCA}_{\mathrm{HI}} ; \sim 1200-750\right.$ years BP), have been identified from Baltic Sea sediments. Here we present sediment records from two sites in the Baltic Sea, and compare the trace metal (As, $\mathrm{Ba}, \mathrm{Cd}, \mathrm{Cu}, \mathrm{Mo}, \mathrm{Ni}$, $\mathrm{Pb}, \mathrm{Re}, \mathrm{Sb}, \mathrm{Tl}, \mathrm{U}, \mathrm{V}, \mathrm{Zn}$ ) enrichments during all three hypoxic intervals. Distinct differences are observed between the intervals and the various elements, highlighting the much stronger perturbation of trace metal cycles during the modern hypoxic interval. Both Mo and $\mathrm{U}$ show a strong correlation with $\mathrm{C}_{\text {org }}$ and very high absolute concentrations, indicative of frequently euxinic bottom waters during hypoxic intervals. During the modern hypoxic interval $\left(\operatorname{Modern}_{\mathrm{HI}}\right)$ comparatively less Mo is sequestered relative to $\mathrm{C}_{\text {org }}$ than in earlier intervals. This suggests partial drawdown of the water column Mo inventory in the modern water column due to persistent euxinia and only partial replenishment of Mo through North Sea inflows. Molybdenum contents in modern sediments are likely also affected by the recent slowdown in input of Mo in association with deposition of Fe and Mn oxides. Strong enrichments of $\mathrm{U}$ in recent sediments confirm that the $\operatorname{Modern}_{\mathrm{HI}}$ is more intense than past intervals. These results suggest that $\mathrm{U}$ is a more reliable indicator for the intensity of bottom water deoxygenation in the Baltic Sea than Mo. Sedimentary Re enrichment commences under mildly reducing conditions, but this element is not further enriched under more reducing conditions. Enrichments of $\mathrm{V}$ are relatively minor for the $\mathrm{MCA}_{\mathrm{HI}}$ and Modern $_{\mathrm{HI}}$, possibly due to strong reservoir effects on $\mathrm{V}$ in the water column, indicating that $\mathrm{V}$ is unreliable as an indicator for the intensity of bottom water 
51 hypoxia in this setting. Furthermore, Ba profiles are strongly influenced by postdepositional remobilization throughout the Holocene. The strong relationship between $\mathrm{C}_{\text {org }}$ and $\mathrm{Ni}, \mathrm{Tl}$ and particularly $\mathrm{Cu}$ suggests that these trace metals can be used to reconstruct the $\mathrm{C}_{\text {org }}$ flux into the sediments. Profiles of $\mathrm{As}, \mathrm{Sb}$ and $\mathrm{Cd}$ and especially $\mathrm{Pb}$ and $\mathrm{Zn}$ are strongly influenced by anthropogenic pollution.

\section{Keywords (max. 6)}

Redox conditions, anthropogenic pollution, aqueous trace metal depletion, molybdenum, uranium

\section{Introduction}

Sedimentary trace metal records have widely been used as proxies for productivity and redox conditions in both modern and ancient aquatic systems (e.g. Calvert and Pedersen, 1993; Morford and Emerson, 1999; Tribovillard et al., 2006; Brumsack, 2006). Sedimentary trace metal concentrations are often low under a welloxygenated water column (e.g. McLennan, 2001), while under low-oxygen conditions their concentrations are generally elevated due to the interplay of several related processes (e.g. Tribovillard et al., 2006).

Trace metals are closely associated with organic material in both the water column and in sediments (e.g. Pedersen and Calvert, 1990; Canfield, 1994; Tribovillard et al., 2006). Under well-ventilated conditions, only a fraction of the organic-bound trace metals in the water column reaches the sediment-water interface, due to efficient remineralization of organic matter in the water column. Under lowoxygen conditions, however, less organic material is remineralized leading to an 
2

increase in the direct input of organic-bound metals to the sediments. Sediments are further enriched in trace metals under these conditions through uptake of trace metals by organic matter at the sediment-water interface.

A second key vector of trace metal transport to sediments is via $\mathrm{Mn}$ - and $\mathrm{Fe}($ oxyhydr)oxides. Many trace metals are adsorbed onto oxide particles, which are highly mobile in seafloor environments where variable redox conditions lead to repeated cycles of dissolution and re-precipitation (e.g. Froelich et al., 1979; Shaw et al., 1990; Tribovillard et al., 2006). These processes can lead to the focusing of trace metals into defined areas of the seafloor (e.g. Lenz et al., 2015a). Although trace metal enrichment may occur under well-oxygenated conditions when metal-bearing Mn- and Fe-oxides are preserved in the sediments (e.g. Schaller et al., 2000), a more common route of enrichment is that metals are released during dissolution of oxides in the surface sediments, and subsequently sequestered in organic matter, sulfide minerals or other reduced authigenic phases (Morford and Emerson, 1999; Tribovillard et al., 2006).

3

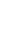

from seawater into sediments and subsequent sequestration in association with organic matter or authigenic minerals. Depending on the metal, enrichment may commence at various stages of bottom water oxygen depletion, i.e. the metal may be sequestered under hypoxic (dissolved oxygen concentrations $<2 \mathrm{mg} / \mathrm{L}$ ), anoxic (no dissolved oxygen) or euxinic conditions (no dissolved oxygen and presence of free sulfide) (Crusius et al., 1996; Tribovillard et al., 2006; Olsson et al., 2017). 
101 Two of the most studied and widely applied redox-sensitive trace metals, Mo and U, have many properties in common (see Algeo and Tribovillard, 2009 for an overview). One key difference between Mo and $U$ is that the presence of free sulfide is a prerequisite for Mo enrichment in sediments. Sulfide is required to convert relatively unreactive seawater molybdate to particle reactive thiomolybdate (Helz et al., 1996). In contrast, authigenic $\mathrm{U}$ sequestration, primarily precipitated as uraninite $\left(\mathrm{UO}_{2}\right)$, already commences when Fe (III) is reduced to Fe (II) (Zheng et al., 2002), making U a potentially more sensitive recorder of minor changes in bottom water oxygen conditions. Another key difference is that water column Mo is actively scavenged by particle Mn- (and sometimes Fe) oxides, which may carry Mo to the sediment-water interface (e.g. Turekian, 1977; Adelson et al., 2001; Sulu-Gambari et al., 2017), whereas $\mathrm{U}$ is generally enriched via diffusion into sediments (e.g. Klinkhammer and Palmer, 1991). These differences in the sequestration of Mo and $U$ can be used for detailed reconstructions of depositional conditions (Algeo and Tribovillard, 2009). In addition, the strong relation between $\mathrm{C}_{\mathrm{org}}$ and $\mathrm{Mo}$ in euxinic environments can be used to identify basin reservoir effects, i.e. the depletion of an element in the water column of a stagnant basin through removal of that specific element to the sediment in excess of resupply by deepwater renewal. In this manner, aqueous Mo may become depleted, resulting in lower sedimentary $\mathrm{Mo} / \mathrm{C}_{\text {org }}$ ratios (Algeo and Lyons, 2006).

Besides Mo and U, Re and V are the most studied and widely used redoxsensitive trace metals (e.g. Morford and Emerson, 1999; Morford et al., 2005). The low crustal abundance of Re results in relatively large, and therefore very distinctive, authigenic enrichments under reducing conditions (Koide et al., 1986; Crusius et al., 1996; Böning et al., 2004). Unlike for instance Mo, Re does not show an affinity for 
$126 \mathrm{Mn}$ - and Fe-oxides and is sequestered in sediments under suboxic conditions after 127 diffusion across the sediment-water interface (e.g. Colodner et al., 1993; Morford et 128 al., 2012). Under well-oxygenated conditions V (in the form of vanadate oxyanions) 129 adsorbs onto Mn- and Fe-oxides (e.g. Wehrli and Stumm, 1989), but is also strongly 130 associated with organic matter (e.g. Beck et al., 2008), so both may be important 131 carriers of $\mathrm{V}$ to deeper waters or the sediment-water interface. Under moderately 132 reducing conditions, $\mathrm{V}(\mathrm{V})$ is reduced to $\mathrm{V}(\mathrm{IV})$, which is more surface reactive and 133 more easily complexes with (in)organic ligands (Emerson and Huested, 1991). This 134 may lead to enhanced sedimentary $\mathrm{V}$ sequestration, but the complexation of V(IV) 135 with dissolved organic matter may also allow it to remain in the aqueous phase (e.g. 136 O'Connor et al., 2015; Olson et al., 2017). In contrast with for instance Mo, V 137 sequestration is not linked to the formation of authigenic sulfides (Algeo and 138 Maynard, 2004). However, under euxinic conditions V can be reduced to V(III), 139 which enables $\mathrm{V}$ sequestration through the precipitation of vanadium(hydr)oxide 140 (Wanty and Goldhaber, 1992).

A prime example, and perhaps the most widely used trace metal to reconstruct marine primary productivity, is sedimentary $\mathrm{Ba}$, which largely reflects biogenic barite $144\left(\mathrm{BaSO}_{4}\right)$, a remnant of decayed organic matter that is preserved in sediments (Bishop, 145 1988; Dymond et al., 1992; Schoepfer et al., 2015). The applicability of sedimentary $146 \mathrm{Ba}$ as a (paleo)productivity proxy seems to be limited to open ocean settings, for 147 example, because a certain water depth $(\sim 1000 \mathrm{~m})$ is needed in order to fully develop 148 the barite-productivity signal settings (Von Breymann et al., 1992; Plewa et al., 2012). 149 Its applicability is further complicated by remobilization of $\mathrm{Ba}$ under reducing 150 conditions (e.g. McManus et al., 1998; Henkel et al., 2012). Despite these 
complications Ingri et al. (2014) showed that sedimentary Ba may represent primary productivity in the Bothnian Bay during the last $5.5 \mathrm{kyr}$.

Furthermore, trace metal enrichments are also used to assess anthropogenic pollution in (semi)modern sediments (e.g. Caccia et al., 2003; Ip et al., 2007). Many trace metals have applications in agriculture and industry, e.g. in fertilizers, pesticides, pigments and lubricants. These trace metals can be transported to the oceans by fluvial and eolian pathways, where they are sequestered in sediments after adsorption onto clay particles and (oxyhydr)oxides and complexation with organic compounds (e.g. Nriagu and Pacyna, 1988; Windom et al., 1989; Liaghati et al., 2004).

The Baltic Sea is an ideal location to assess how changes in bottom water oxygen, primary productivity and anthropogenic pollution are recorded by trace metals in marine sediments. Its geographic configuration, i.e. landlocked with a restricted connection to the open ocean (Fig. 1a), in combination with excessive anthropogenic nutrient input (e.g. Gustafsson et al., 2012), has resulted in a tenfold increase of the hypoxic area over the past century (Carstensen et al., 2014), creating the world's largest human-induced "dead zone" (Diaz and Rosenberg, 2008). The modern Baltic hypoxic interval (henceforth Modern $_{\mathrm{HI}}$ ), was preceded by two previous hypoxic intervals during the Holocene (Zillén et al., 2008). The first hypoxic interval coincided with the Holocene Thermal Maximum $\left(\mathrm{HTM}_{\mathrm{HI}} ; \sim 8\right.$ and 4 ka before present - BP). The second interval of widespread hypoxia in the Baltic Sea coincided with the Medieval Climate Anomaly (MCA $\mathrm{HI}_{1} ; 1200-750$ years BP). 

characterized by high organic carbon $\left(\mathrm{C}_{\text {org }}\right)$ and molybdenum (Mo) contents (Jilbert and Slomp, 2013a; Dijkstra et al., 2016; Hardisty et al., 2016; Papadomanolaki et al., 178 2018), indicative of free sulfide in bottom waters (Helz et al., 1996). Previous studies 179 have drawn various conclusions about the environmental conditions during each of the hypoxic intervals. High-resolution records of Mo enrichment indicate that the development of the Modern ${ }_{\mathrm{HI}}$ was more rapid than the development of the $\mathrm{MCA}_{\mathrm{HI}}$ and $\mathrm{HTM}_{\mathrm{HI}}$, while the maximum intensity of hypoxia was similar for all three events (Jilbert and Slomp, 2013a). In contrast, Hardisty et al. (2016) concluded, based on Mo isotopes, that reducing conditions during the $\mathrm{MCA}_{\mathrm{HI}}$ and $\mathrm{HTM}_{\mathrm{HI}}$ were probably more intense than during the Modern ${ }_{\mathrm{HI}}$. Focusing on the areal extent, rather than intensity, of hypoxia, Lenz et al. (2015a) concluded on the basis of sedimentary Fe records that the present-day hypoxic area is larger than that in the past.

Here we present a comprehensive analysis of trace metal enrichments during the three hypoxic intervals from two sites in the central Baltic Sea. By considering a large number of trace metals together, we are able to test multiple hypotheses about the mechanisms of trace metal enrichment, and the suitability of trace metals for paleoenvironmental reconstructions in this setting. Specifically, we investigate (1) the sensitivity of known redox-sensitive trace metal enrichments, i.e. Mo, U, Re and V, to variable redox conditions, (2) which trace metals may be reliable proxies for the organic carbon $\left(\mathrm{C}_{\mathrm{org}}\right)$ flux into the sediments and (3) the effect of anthropogenic 197 pollution on sedimentary trace metal records. We have generated complete discrete198 sample records of 13 trace metals (As, Ba, Cd, Cu, Mo, Ni, Pb, Re, Sb, Tl, U, V, Zn), 199 as well as major and minor sediment components (Al, Fe, S, $\mathrm{C}_{\text {org }}$ ), for the entire 
sediment column spanning the three hypoxic intervals and the intervening oxic

201 periods, at two sites in the Baltic Sea (Fig. 1). Additionally, we present Laser 202 Ablation-Inductively Coupled Plasma-Mass Spectrometry (LA-ICP-MS) line-scan 203 Mo and U data for the three intervals at one of the two study sites. The LA-ICP-MS 204 records allow an orders-of-magnitude increase in the depth resolution of the trace metal profiles, facilitating robust analysis of relative enrichments between Mo and $\mathrm{U}$, and investigation of how the two elements respond to short-timescale changes in oxygen conditions.

\section{Materials and methods}

\subsection{Study site}

Sediment samples were retrieved from two different localities in the central part of the Baltic Sea during two research cruises with $R / V$ Aranda in May-June 2009 and August 2013. Multicores (0-35 cm below seafloor; cmbsf) and gravity cores $(\sim 25-$ $440 \mathrm{cmbsf})$ were collected from site F80 in the Fårö Deep $\left(58.0000^{\circ} \mathrm{N}, 19.8968^{\circ} \mathrm{E}\right.$, $191 \mathrm{~m}$ water depth) and from site LL19 in the Northern Gotland Basin $\left(58.8807^{\circ} \mathrm{N}\right.$, $20.3108^{\circ} \mathrm{E}, 169 \mathrm{~m}$ water depth; Fig. 1$)$ in 2009 . An additional short core $(0-55 \mathrm{cmbsf})$ was taken at site F80 in 2013 with a GEMAX corer.

\subsection{Processing of the sediment cores}

The multicores and GEMAX core were sliced on board the ship under an oxygen-free atmosphere at in-situ bottom water temperature. The resolution of the sediment slices was $0.5 \mathrm{~cm}$ for $0-2 \mathrm{cmbsf}, 1 \mathrm{~cm}$ for 2-10 $\mathrm{cmbsf}$ and $2 \mathrm{~cm}$ from 10 
analysed in this study (0-10 cmbsf). The gravity cores were stored at $4{ }^{\circ} \mathrm{C}$ and sliced under an oxygen-free atmosphere in the laboratory at Utrecht University at a resolution of $1 \mathrm{~cm}$. All sediment samples were freeze-dried and weighed before and after freeze-drying in order to determine the water content and to calculate porosity. The samples were subsequently powdered and homogenized using an agate mortar and pestle in an oxygen-free atmosphere.

\subsection{Organic carbon content}

Organic carbon content data $\left(\mathrm{C}_{\text {org }}\right)$ for the 2009 cores was generated and published by Jilbert and Slomp (2013a). For the 2013 GEMAX core 0.1-0.2 $\mathrm{g}$ of freeze-dried and powdered sediment sample was weighed in $15 \mathrm{ml}$ centrifuge tubes and $7.5 \mathrm{ml}$ of $1 \mathrm{M} \mathrm{HCl}$ was added to dissolve carbonates. After four hours on a shaker the acid was removed through centrifugation and fresh $1 \mathrm{M} \mathrm{HCl}$ was added after which the samples were left on a shaker overnight. The acid was then removed again after centrifugation and samples were washed twice with milliQ water, and dried at $60^{\circ} \mathrm{C}$ for 72 hours. The dried residues were then weighed again to determine the weight loss. Finally, the samples were powdered and homogenized and $\sim 5 \mathrm{mg}$ of each sample was weighed in a tinfoil cup. Total carbon analyses were performed using a Fisons Instruments NA 1500 NCS analyzer. Obtained results were normalized to in-house standards, acetanilide, atropine and nicotinamide. An internationally certified soil standard (IVA2) was measured after each 10 samples to determine the accuracy and precision of our analyses. The certified value for IVA2 is $0.732 \mathrm{wt} \% \mathrm{C}$, our obtained mean value was 0.726 wt.\% $\mathrm{C}$ with a standard deviation of 0.014 wt.\% C. Finally, $\mathrm{C}_{\text {org }}$ was calculated upon correction for the weight loss due to the decalcification. An 
average analytical uncertainty of 0.08 wt.\% was calculated based on duplicate analyses of sediment samples.

\subsection{Trace metal concentrations}

For the determination of sedimentary trace metal concentrations about $125 \mathrm{mg}$ of freeze-dried and powdered sediment sample was weighed in $30 \mathrm{ml}$ Teflon vessels. Subsequently $2.5 \mathrm{ml}$ of mixed acid $\left(\mathrm{HClO}_{4}: \mathrm{HNO}_{3}, 3: 2\right)$ and $2.5 \mathrm{ml} 40 \% \mathrm{HF}$ were added and the vessels were left overnight on a hotplate at $90^{\circ} \mathrm{C}$. The following day the lids of the vessels were removed and the extracts were heated to $140^{\circ} \mathrm{C}$ to evaporate the acids. The remaining residues were then dissolved in $25 \mathrm{ml} 4.5 \% \mathrm{HNO}_{3}$ and left overnight on a hotplate at $90^{\circ} \mathrm{C}$ again. The dilution of the final solutions was determined by weighing the vessels, after which the solutions were analysed by Inductively Coupled Plasma-Optical Emission Spectrometry (ICP-OES; Al, Fe and S published previously in Jilbert and Slomp, 2013a and Lenz et al., 2015a) and by Inductively Coupled Plasma-Mass Spectometry (ICP-MS; As, Cd, Cu, Mo, $\mathrm{Ni}, \mathrm{Pb}$, Re, Sb, Tl, U, V and Zn). For the latter analyses, we used an XSeries II ICP-MS (Thermo Fisher Scientific) equipped with a Peltier cooled, low-volume conical spray chamber fitted with a micro nebulizer, a micro pump and a FAST system on the autosampler (SC-4 DX; Elemental Scientific), to enhance stability, enable fast washout and minimum cross contamination and optimize sample throughput. The accuracy (recovery) was generally between 95 and 105\% for all reported elements based on in-house standards. The average analytical uncertainty based on duplicates, in-house standards and laboratory reference material (ISE-921) was 2\% for As, $1 \%$ for $\mathrm{Cd}, 2 \%$ for $\mathrm{Cu}, 1 \%$ for $\mathrm{Mo}, 2 \%$ for $\mathrm{Ni}, 2 \%$ for $\mathrm{Pb}, 8 \%$ for $\mathrm{Re}, 2 \%$ for $\mathrm{Sb}, 4 \%$ for $\mathrm{Tl}, 2 \%$ for $\mathrm{U}, 2 \%$ for $\mathrm{V}$ and $2 \%$ for $\mathrm{Zn}$. 
Sections of the sediment cores from F80 (2009 gravity core and 2013 GEMAX core) were prepared for LA-ICP-MS analysis by resin embedding. From the gravity core, U-channels of sediment $(20 \times 2 \times 1 \mathrm{~cm})$ were sampled horizontally from the open core surface as described in Jilbert et al. (2008) and transferred immediately to an $\mathrm{N}_{2}$-filled glovebox. A total of $180 \mathrm{~cm}$ of sediment, including the laminated intervals corresponding to the $\mathrm{MCA}_{\mathrm{HI}}$ and $\mathrm{HTM}_{\mathrm{HI}}$, were sampled in this way. From the GEMAX core, a vertical column of miniature sub-cores of sediment ( 8 sub-cores in total, each $1 \mathrm{~cm}$ diameter, $7 \mathrm{~cm}$ length) was taken as described in Jilbert and Slomp 284 (2013a). The entire sub-coring operation was performed in a $\mathrm{N}_{2}$-filled glove bag and the sub-cores were transferred to an $\mathrm{N}_{2}$-filled glovebox. All U-channels and sub-cores were then dehydrated with argon-purged acetone, fixed in Spurr's epoxy resin, and sliced to reveal the interior surface using a water-cooled rock saw. The interior surfaces were polished prior to subsequent analysis. LA-ICP-MS instrument at Utrecht University. The ablation chamber sits on a mobile stage. Line scan profiles were generated by focusing a pulsed argon-fluoride excimer laser beam $\left(120 \mu \mathrm{m}\right.$ spot size, $193 \mathrm{~nm}$ wavelength, $10 \mathrm{~Hz}$ repetition rate, $8 \mathrm{~J} \mathrm{~cm}^{-2}$ energy density) onto the moving sample surface and ablating material into a high mass-resolution ICP-MS (Thermo Element 2) via a He-Ar carrier gas. During line 295 scans the stage velocity was optimized to $0.0275 \mathrm{~mm} \mathrm{~s}^{-1}$ for high spatial resolution 296 measurements (Hennekam et al., 2015). Count rates of the isotopes ${ }^{27} \mathrm{Al},{ }^{98} \mathrm{Mo}$ and $297{ }^{238} \mathrm{U}$, among a range of other elements, were determined continuously at a measurement frequency of approximately $1 \mathrm{~Hz}$. 

compaction, such that the length of each line scan is less than that of the original U-

301 channel or sub-core. To correct for compaction effects, the data from each LA-ICP302 MS line scan was linearly re-scaled to the initial length of the sub-core. Subsequently, 303 line scan data were fine-tuned by alignment to ICP-OES or ICP-MS data of discrete 304 samples from the corresponding interval.

Raw LA-ICP-MS count data were converted to elemental compositional ratios 306 via the two-step linear calibration procedure described in Jilbert and Slomp (2013a). Briefly, count rates of each element in the line-scan data were converted to preliminary concentrations using one-point sensitivity factors (counts/ppm) determined from a glass standard (NIST 610) at equivalent measurement settings.

310 Preliminary concentrations of ${ }^{98} \mathrm{Mo}$ and ${ }^{238} \mathrm{U}$ were then normalized to ${ }^{27} \mathrm{Al}$ to correct 311 for variable ablation yield during line scanning. The resulting ratios, corrected for 312 natural isotopic abundances of each element, were further corrected using a linear 313 regression against $\mathrm{Mo} / \mathrm{Al}$ and $\mathrm{U} / \mathrm{Al}$ concentration ratios of the equivalent sediment 314 interval determined by discrete sample ICP-OES or ICP-MS analysis. This second 315 step corrects for any offset between the sensitivity factors of the elements in the 316 sediment sample relative to the standard glass.

\subsection{Sediment chronologies}

Age-depth models for the sediment cores used in this study were previously generated by Jilbert and Slomp (2013a) and Lenz et al. (2015a). For the present study

321 we choose to show our data against depth instead of time. We have, however, 322 included the dates, following Lenz et al. (2015a), in the supplementary data file. We 323 follow Jilbert and Slomp (2013a) concerning the position of the Modern ${ }_{\mathrm{HI}}, \mathrm{MCA}_{\mathrm{HI}}$ 
and the $\mathrm{HTM}_{\mathrm{HI}}$. For the purposes of this study we do not discern different sub-events within the $\mathrm{MCA}_{\mathrm{HI}}$ and $\mathrm{HTM}_{\mathrm{HI}}$.

\section{Results}

\subsection{Trace metals in the Fårö Deep (site F80) and Northern Gotland Basin (site LL19)}

The hypoxic intervals in the Fårö Deep are characterized by strong enrichments in sedimentary $\mathrm{C}_{\text {org }}$ (Fig. 2a). Maximum values are similar ( 10 wt. \%; Table 1) for the three hypoxic events when the top sediments consisting of fresh, nondegraded organic material, the so-called "fluffy" layer, are left out of consideration. Both Mo and $U$ are also strongly enriched in the sediments of all three hypoxic intervals (Fig. 2a; Table 1). Maximum values for Mo (>300 ppm) are recorded during the $\mathrm{HTM}_{\mathrm{HI}}$. Background Mo concentrations, i.e. in the intervening oxic intervals, are $25 \mathrm{ppm}$ on average (Table 1). Uranium concentrations progressively increase from the $\mathrm{HTM}_{\mathrm{HI}}$ to the Modern $\mathrm{HI}$, hence the present-day U concentration is the highest in the record. In contrast with $\mathrm{C}_{\mathrm{org}}$, Mo and $\mathrm{U}$, Re shows rather constant concentrations throughout the studied sediment sequence, without significant enrichments during the hypoxic intervals (Fig. 2a; Table 1). Both $\mathrm{V}$ and $\mathrm{Ba}$ are strongly enriched during the $\mathrm{HTM}_{\mathrm{HI}}$, but not during other intervals, in particular the Modern ${ }_{\mathrm{HI}}$.

The profiles of $\mathrm{C}_{\mathrm{org}}$ and trace metals for the Northern Gotland Basin site LL19 (Fig. 2b) largely resemble those for the Fårö Deep (Fig. 2a). Maximum $\mathrm{C}_{\text {org }}$ values for the three hypoxic intervals are slightly lower than in the Fårö Deep, i.e. around 8 wt. $\%$ (Fig. 2b; Table 2). Maximum values for Mo are recorded during the $\mathrm{MCA}_{\mathrm{HI}}$ and $\mathrm{HTM}_{\mathrm{HI}}$, with somewhat lower maximum values during the Modern $\mathrm{HI}$ (Fig. 2b). However, background Mo concentrations in the intervening oxic intervals ( $6 \mathrm{ppm})$ 
are much lower than in the Fårö Deep (Tables 1 and 2). Absolute U concentrations are also lower in the sediments of the Northern Gotland Basin, but the trend in $U$ concentrations is the same as for the Fårö Deep, i.e. progressively increasing in the order $\mathrm{HTM}_{\mathrm{HI}}-\mathrm{MCA}_{\mathrm{HI}}-\mathrm{Modern}_{\mathrm{HI}}$. In contrast with the Fårö Deep, distinct enrichments in Re are observed during all three hypoxic intervals in the Northern Gotland Basin (Fig. 2b). Moreover, background Re concentrations in the intervening oxic intervals (10 ppb) are generally lower than in the Fårö Deep. Again, both V and Ba are strongly enriched during the $\mathrm{HTM}_{\mathrm{HI}}$, but strong enrichments are absent from the other intervals.

The other trace metals all show their strongest enrichments coinciding with the

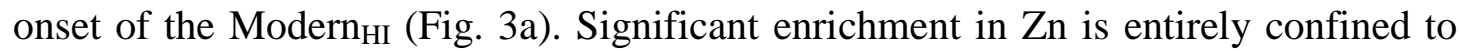
the Modern $_{\mathrm{HI}}$, while for $\mathrm{Pb}$ there is also a small enrichment towards the end of the $\mathrm{MCA}_{\mathrm{HI}}$, followed by a rapid drop and a gradual increase towards the Modern HI $_{\text {Fig. }}$ 3a). For $\mathrm{Sb}$ and $\mathrm{As}$ we observe both a strong $\operatorname{Modern}_{\mathrm{HI}}$-related enrichment and moderate enrichments during both the $\mathrm{MCA}_{\mathrm{HI}}$ and $\mathrm{HTM}_{\mathrm{HI}}$, which generally follow the profiles of $\mathrm{S}$ and $\mathrm{Fe}$ (Fig. 3a). Enrichments in $\mathrm{Cd}, \mathrm{Ni}, \mathrm{Tl}$ and $\mathrm{Cu}$ are more similar to those of $\mathrm{C}_{\text {org }}$ and Mo. Even the smaller variations in $\mathrm{C}_{\text {org }}$ and Mo, e.g. the maximum around $410 \mathrm{cmbsf}$ (Fig. 3a), are clearly expressed, and the absolute magnitude of the enrichments in $\mathrm{Ni}, \mathrm{Tl}$ and $\mathrm{Cu}$ is rather similar for all three of the hypoxic events.

As for the Fårö Deep, significant enrichment in $\mathrm{Zn}$ in the Northern Gotland Basin is confined to the $\operatorname{Modern}_{\mathrm{HI}}$, while for $\mathrm{Pb}$ there is also a small enrichment visible towards the end of the $\mathrm{MCA}_{\mathrm{HI}}$. For $\mathrm{Sb}, \mathrm{As}, \mathrm{Cd}, \mathrm{Ni} \mathrm{Tl}$, and $\mathrm{Cu}$, there are, besides the strong Modern $_{\mathrm{HI}}$-related enrichment, clear enrichments visible during both 
the $\mathrm{MCA}_{\mathrm{HI}}$ and $\mathrm{HTM}_{\mathrm{HI}}$ (Fig. 3b). The magnitude of the enrichments in $\mathrm{Ni}, \mathrm{Tl}$ and $\mathrm{Cu}$ is again similar for the three different hypoxic intervals, while for $\mathrm{Sb}$, As and $\mathrm{Cd}$, the enrichment during the Modern $\mathrm{HI}_{\mathrm{I}}$ is much larger than the enrichments during the $\mathrm{MCA}_{\mathrm{HI}}$ and $\mathrm{HTM}_{\mathrm{HI}}$ (Fig. 3b).

\subsection{High-resolution molybdenum and uranium records}

Trends in the high-resolution Mo and U LA-ICP-MS data for each of the hypoxic intervals in the Fårö Deep (Fig. 4) are in good agreement with the results for the discrete samples (Fig. 2a). However, the LA-ICP-MS data reveal significantly more internal variability within these intervals, and rapid changes in enrichment as previously demonstrated by Jilbert and Slomp (2013a) for shorter sections of the Holocene record. Moreover, the LA-ICP-MS data clearly show that U enrichment increases gradually at the onset of centennial-scale 'hypoxic events' within the hypoxic intervals (zoom sections labeled 'onset' in Fig. 4). In contrast, Mo enrichments increase rapidly beyond a certain point in the development of each event.

The contrast between relative Mo and $\mathrm{U}$ enrichments in each hypoxic interval is further illustrated by the LA-ICP-MS data. Although both elements are clearly enriched in all intervals, the $\mathrm{Mo} / \mathrm{U}$ ratio differs markedly between $\mathrm{HTM}_{\mathrm{HI}}, \mathrm{MCA}_{\mathrm{HI}}$ and Modern ${ }_{\mathrm{HI}}$. In hypoxic events within $\mathrm{HTM}_{\mathrm{HI}}, \mathrm{Mo} / \mathrm{U}$ oscillates around 10 , while in $\mathrm{MCA}_{\mathrm{HI}}$ the average value is close to 5 , and for Modern $\mathrm{HI}$ the average value is close to 3.5 (Fig. 4).

\section{Discussion}




\subsection{Molybdenum and uranium as proxies of bottom water redox conditions}

The extremely high concentrations of Mo during the three hypoxic intervals can only be explained by persistent euxinic conditions at these times (e.g. Scott and Lyons, 2012), as concluded by previous studies of Baltic Sea sediments (Jilbert and Slomp, 2013a; Dijkstra et al., 2016). The similar maximum values of $\mathrm{C}_{\text {org }}$ and Mo for the three hypoxic intervals have previously been interpreted to indicate that the intensity of hypoxia during each interval was similar (Jilbert and Slomp, 2013a). However, the increase in $\mathrm{U}$ concentrations from the $\mathrm{HTM}_{\mathrm{HI}}$ to the Modern $\mathrm{HI}_{\mathrm{I}}$ observed in our new data causes us to reassess this conclusion. Taken alone, the $\mathrm{U}$ records suggest that the intensity of the hypoxic intervals has in fact increased towards the present day. This would imply that increased anthropogenic nutrient inputs to the Baltic during the $20^{\text {th }}$ century (e.g. Gustafsson et al., 2012; Carstensen et al., 2014) have led to a perturbation of trace metal cycling that exceeds the natural variability observed in earlier hypoxic intervals.

The average background Mo concentration of 25 ppm in the Fårö Deep suggests that even outside the hypoxic intervals, bottom waters in this location may have been intermittently euxinic (Scott and Lyons, 2012). The lower average background Mo concentration in the Northern Gotland Basin (6 ppm), although substantially above the crustal average ( 1-2 ppm; McLennan, 2001), is significantly below that of the Fårö Deep, suggesting that sulfide remained restricted to pore waters (Scott and Lyons, 2012). This difference can be attributed to the greater water depth of the Fårö Deep (191 m versus 169 m), making it naturally more susceptible to deoxygenation. The relatively early onset of $U$ enrichment compared to Mo during short-timescale hypoxic events within the $\mathrm{HTM}_{\mathrm{HI}}, \mathrm{MCA}_{\mathrm{HI}}$ and Modern $\mathrm{HI}_{\mathrm{I}}$ in the Fårö 
424 Deep (Fig. 4) is likely related to the fact that sedimentary U enrichment via the 425 reduced phase $\mathrm{UO}_{2}$ commences in the zone of Fe oxide reduction (Zheng et al., 2002).

426 Whereas Mo enrichment via thiomolybdates requires the presence of free sulfide 427 (Helz et al., 1996). During the onset of a hypoxic event, progressive stagnation of 428 deep water masses may have resulted in a staggered timing of $U$ and Mo enrichment.

429 However, once a hypoxic event is initiated, the two elements show strongly correlated 430 patterns of enrichment on short timescales (see coincident peaks in Fig. 4). We note 431 that this interpretation implies that sedimentary $U$ and Mo contents are determined by 432 processes that occur very close to the sediment-water interface.

\subsection{Drawdown of water column molybdenum}

The regression slope between sedimentary $\mathrm{Mo}$ and $\mathrm{C}_{\text {org }}$ content has been shown to differ between modern (intermittently) hypoxic marine basins as a function of the degree of restriction of the sub-chemocline water mass (Algeo and Lyons, 438 2006). The $\mathrm{Mo} / \mathrm{C}_{\text {org }}$ ratio has been successfully applied as a proxy to determine extent 439 of water mass restriction in marine basins during for example the Mesozoic Oceanic 440 Anoxic Events (e.g. McArthur et al., 2008; van Helmond et al., 2014), and also to 441 study past hypoxia in the Baltic Sea (Jilbert and Slomp, 2013a). The latter study 442 showed that the $\mathrm{Mo} / \mathrm{C}_{\text {org }}$ data for both the Northern Gotland Basin and the Fårö Deep 443 during the $\mathrm{MCA}_{\mathrm{HI}}$ and $\mathrm{HTM}_{\mathrm{HI}}$ plot close to the regression slope for (semi)modern 444 sediments from Saanich Inlet, considered to be the least restricted of the four modern 445 euxinic basins studied by Algeo and Lyons (2006) with a deep water renewal period 446 of $\sim 1.5$ years. Therefore Jilbert and Slomp (2013a) concluded that the basin reservoir 447 effect in the Baltic Sea was negligible. Our new datasets show (Fig. 5a, b), that the $448 \mathrm{Mo} / \mathrm{C}_{\text {org }}$ data for the Modern $_{\mathrm{HI}}$ plot considerably below the $\mathrm{Mo} / \mathrm{C}_{\text {org }}$ data for the 
$\mathrm{MCA}_{\mathrm{HI}}$ and $\mathrm{HTM}_{\mathrm{HI}}$. The regression line would have been even more flat if the "fluffy-layer" had been included as well because of the relatively high $\mathrm{C}_{\text {org }}$ content in this top layer (open symbols in Fig. 5a, b). The flatter regression line for $\mathrm{Mo} / \mathrm{C}_{\text {org }}$ during the Modern $_{\mathrm{HI}}$ implies partial drawdown of the water column Mo inventory, and thus the potential impact of a basin reservoir effect on sedimentary Mo data. A basin reservoir effect may have important implications, for example, for the interpretation of $\delta^{98}$ Mo records from the Baltic Sea (e.g. Hardisty et al., 2016). Based on these findings we conclude that $U$ is a more reliable indicator of bottom water hypoxia intensity than Mo in the Baltic Sea and potentially also in other euxinic basins affected by a reservoir effect.

Both the Northern Gotland Basin and Fårö Deep are located in the central part of the Baltic Proper, in the pathway followed by episodically occurring Major Baltic Inflows (MBIs; Mätthaus and Franck, 1992; Lass and Matthäus, 1996). These MBIs introduce large quantities of relatively high-saline and well-oxygenated North Sea waters into the Baltic Sea following meteorological events (e.g. Schinke and Matthäus, 1998). The relatively high density of the waters introduced during MBIs leads to bottom water ventilation (e.g. Mohrholz et al., 2015). Besides oxygen, the North Sea waters contain trace metals, thereby potentially replenishing the water column Mo inventory. However, not all MBIs penetrate into the more remote subbasins of the Baltic Sea, such as the Landsort Deep (Morholz et al., 2015). Hence, the sub-basins further downstream along the path of the MBIs may be expected to show longer residence times and thus comparatively severe drawdown of water column Mo during hypoxic intervals. To test this hypothesis, we compiled $\mathrm{Mo} / \mathrm{C}_{\text {org }}$ data for the three hypoxic intervals in the Landsort Deep Modern $_{\mathrm{HI}}$ - Lenz et al., 2015b, site LD1; 
$\mathrm{MCA}_{\mathrm{HI}}$ and $\mathrm{HTM}_{\mathrm{HI}}$ - Dijkstra et al., 2016, IODP exp. 347 site M0063; Fig. 1). The cross-plot of Mo and $\mathrm{C}_{\text {org }}$ data for the Landsort Deep shows relatively flat regression slopes for all three the hypoxic events (Fig. 5c). In contrast with the data for the Northern Gotland Basin and the Fårö Deep and a previous study for the Landsort Deep by Hardisty et al. (2016), this suggests that there was water column Mo depletion in the Landsort Deep during all three hypoxic intervals. Our explanation is supported by the relatively low concentrations of aqueous Mo throughout the water column in both the Gotland Deep and the Landsort Deep (Nägler et al., 2011; Noordmann et al., 2015; Bauer et al., 2017).

The Modern $_{\mathrm{HI}}$ developed more rapidly than any past event of hypoxia in the Baltic Sea during the Holocene (Jilbert and Slomp, 2013a). This more rapid development of hypoxia may have contributed to drawdown of water column Mo. Furthermore, the water exchange between the Baltic Sea and the North Sea has decreased over the last $8 \mathrm{kyr}$ (e.g. Gustafsson and Westman, 2002), leading to the relatively long modern residence time for water in the Baltic Sea ( $\sim 30$ years; e.g. Döös et al., 2004), thereby increasing the chance for water column Mo drawdown to occur. Finally, the present-day hypoxic and euxinic area is large (e.g. Carstensen et al., 2014), and hypoxia is not only confined to the deeper parts of the basin but is also widely present in shelf and coastal areas (Conley et al., 2011; Lenz et al., 2015a). These hypoxic shelf and coastal areas, e.g. in the Belt Seas, the Finnish Archipelago Sea, the Gulf of Finland and the Stockholm Archipelago, cover thousands of square kilometers, substantially increasing, the area in the Baltic Sea where Mo is potentially sequestered, when compared to the deeper parts of the basin alone. The amount of Mo sequestered in these shelf and coastal areas is limited, however (Jokinen et al., 2018), 
since they are generally only seasonally hypoxic and only sporadically euxinic (e.g. Conley et al., 2011). However, during the $\mathrm{HTM}_{\mathrm{HI}}$ large parts of the, present-day wellventilated, Bothnian Sea were still hypoxic (e.g. Zillén et al., 2008) and potentially even euxinic (Jilbert et al., 2015), suggesting that the hypoxic and euxinic area may

503 have been equally large or even larger during the $\mathrm{HTM}_{\mathrm{HI}}$. We therefore suggest that 504 the rapid development of the Modern $_{\mathrm{HI}}$, in combination with decreasing water exchange between the open ocean and the Baltic Sea, has led to the observed lower sedimentary Mo sequestration and implied drawdown of the water column Mo inventory.

509 Cross-plots of the enrichment factors of Mo and U from the discrete sample analyses 510 show (Fig. 6) that the depositional system in the Baltic Sea is characterized by an 511 active oxide particulate shuttle, comparable with for instance the Cariaco Basin 512 (Algeo and Tribovillard, 2009). The active oxide particulate shuttle in the Baltic Sea 513 leads to generally elevated $\mathrm{Mo} / \mathrm{U}$ values relative to unrestricted marine anoxic settings 514 (Fig. 6), because in contrast with U, Mo is actively scavenged by particle Mn- (and 515 sometimes Fe) oxides, which may carry Mo to the sediment-water interface, thereby 516 enhancing its sequestration potential (e.g. Turekian, 1977; Adelson et al., 2001; Sulu517 Gambari et al., 2017). However, samples from the Modern $_{\mathrm{HI}}$ plot towards the upper 518 boundary of, or outside, the particulate shuttle zone identified by Algeo and 519 Tribovillard (2009), indicating a shift towards lower Mo/U as also seen in the LA520 ICP-MS data (Fig. 4), and as observed in other anoxic basins (Algeo and Tribovillard, 521 2009). We suggest that at our study sites in the Baltic Sea, this evolution is a direct 522 result of the decline in the rate of $\mathrm{Fe}$ and $\mathrm{Mn}$ particulate shuttling in recent decades 523 due to hypoxia, as demonstrated by Lenz et al. (2015a). Lower Fe and Mn particle 
524 shuttling will have reduced the supply of Mo to our study sites (e.g. Turekian, 1977;

525 Adelson et al., 2001; Sulu-Gambari et al., 2017), contributing to the observed trends 526 in sedimentary Mo (Figs. 2, 4, 5).

527 interval.

\subsection{Rhenium and vanadium as proxies of bottom water redox conditions}

Authigenic Re sequestration occurs under suboxic, relatively mildly reducing conditions (Crusius et al., 1996; Morford et al., 2005). Our results confirm that Re is a sensitive recorder of mildly reducing conditions, particularly because of its large enrichment factor relative to crustal average values (Koide et al., 1986). The sedimentary Re profiles of the Fårö Deep and Northern Gotland Basin show large differences, which we attribute to the different background redox conditions for the two studied sites. The relatively reducing background conditions in the Fårö Deep caused a (nearly) continuously sequestration of Re throughout the studied interval (i.e. during the last $\sim 7 \mathrm{kyr}$; Jilbert and Slomp, 2013a), while in the Northern Gotland Basin conditions for enhanced Re sequestration were only reached during the three hypoxic intervals. The lack of further enrichment during the more intensely reducing conditions of the $\mathrm{HTM}_{\mathrm{HI}}$, $\mathrm{MCA}_{\mathrm{HI}}$ and $\operatorname{Modern}_{\mathrm{HI}}$, suggests that sedimentary $\mathrm{Re}$ concentrations are not useful as a quantitative proxy for the intensity of hypoxia in the central Baltic Sea. The contemporaneous presence of sulfide and Re in pore waters implies that sedimentary Re sequestration is not enhanced by the presence of sulfide (e.g. Colodner et al., 1993; Olson et al., 2017). Therefore, enrichment of Re does not accelerate as the intensity of reducing conditions increases within the hypoxic 
550 paleoredox conditions and generally shows strong sedimentary enrichments under

551 reducing conditions, with relative enrichments similar to those found for Mo and U

552 (e.g. Algeo and Maynard, 2004; Tribovillard et al., 2006). The sedimentary V records

553 presented in this study are, however, very different from the records for Mo and U.

554 Particularly the absence of (strong) enrichments during the Modern ${ }_{\mathrm{HI}}$ is striking (Fig. $5552)$.

The absence of (strong) enrichments in $\mathrm{V}$ might theoretically be related to 558 complexation of $\mathrm{V}$ with dissolved organic matter under reducing conditions 559 (Brumsack and Gieskes, 1983; Beck et al., 2008). The formation of dissolved metal560 organic complexes leads to retention of $\mathrm{V}$ in pore waters and the consequent absence 561 of sedimentary V enrichments (e.g. O'Connor et al., 2015; Olson et al., 2017). The 562 problem with this explanation for the records presented here is that $\mathrm{C}_{\text {org }}$ concentrations 563 for the three hypoxic intervals are very similar, so large differences in dissolved 564 organic matter concentrations between the hypoxic intervals are not expected. The 565 effect of complexation of $\mathrm{V}$ with dissolved organic matter should therefore have been 566 similar for the three hypoxic intervals. The type of organic matter and the degree to 567 which it has decayed may, however, also be of importance. Particularly the degree of 568 decay of organic matter is probably very different for the Modern $\mathrm{HI}_{\mathrm{I}}$ and $\mathrm{MCA}_{\mathrm{HI}}$ 569 compared to the $\mathrm{HTM}_{\mathrm{HI}}$.

571 An alternative explanation for the unexpected $\mathrm{V}$ profiles might be found in 572 variations in the strength of the particulate shuttle. Water column vanadate adsorbs 573 onto Mn- and Fe(oxyhydr)oxides (e.g. Wehrli and Stumm, 1989; Morford et al., 
574 2005), which can then carry $\mathrm{V}$ to deeper areas, thereby increasing the potential for 575 sedimentary V sequestration. The more muted Fe shuttle during the Modern ${ }_{\mathrm{HI}}$ (Lenz et 576 al., 2015a), could therefore be a reason for the absence of sedimentary V enrichments 577 during the Modern ${ }_{\mathrm{HI}}$. Again however, this interpretation cannot fully explain the $\mathrm{V}$ 578 profiles, since the rate of shuttling was significantly higher during the $\mathrm{MCA}_{\mathrm{HI}}$ - as 579 indicated by strong enrichments of Fe and S at this time (Fig. 2) - but V enrichments 580 were similarly low to those in the Modern $_{\mathrm{HI}}$.

Two studies of water column V concentrations in the modern Baltic Sea demonstrated a significant depletion ( $>60 \%$ ) of this element relative to conservative mixing of freshwater and seawater (Prange and Kremling, 1985; Bauer et al., 2017). Prange and Kremling (1985) also showed V depletion to be significantly greater than Mo or U depletion (which were effectively conservative with respect to seawater mixing at the studied locations), and attributed this effect to the particle reactivity of 588 seawater vanadate during mixing in the turbid waters of the Baltic Sea. In addition, the $\mathrm{V}$ that enters the Baltic Sea via riverine pathways is already (partly) removed upon estuarine mixing (Prange and Kremling, 1985). These observations imply that V in the Baltic Sea is subject to an even greater reservoir effect than Mo, and hence that the sedimentary record of $\mathrm{V}$ enrichment may be strongly impacted by basin-wide 593 drawdown of water column V. As described above for Mo (Section 4.2), the reservoir 594 effect is more likely to be activated during the recent hypoxic intervals $\left(\mathrm{MCA}_{\mathrm{HI}}\right.$ and 595 Modern $_{\mathrm{HI}}$ ) than during the $\mathrm{HTM}_{\mathrm{HI}}$, due to the lower replenishment rate of seawater vanadate in the late Holocene bathymetric configuration of the Baltic. This would 597 explain why the $\mathrm{MCA}_{\mathrm{HI}}$ and Modern $_{\mathrm{HI}}$ ) show strongly muted $\mathrm{V}$ enrichments relative 598 to the $\mathrm{HTM}_{\mathrm{HI}}$ (Fig. 2). 

the Baltic Sea

602 Sedimentary Ba concentrations are widely used as a proxy for productivity (e.g. 603 Bishop, 1988; Dymond et al., 1992; Schoepfer et al., 2015). The Ba profiles in this 604 study are, however, unrelated to $\mathrm{C}_{\text {org }}$ (Fig. 2; with the exception of the maximum 605 during the $\mathrm{HTM}_{\mathrm{HI}}$ ), suggesting that Ba profiles in the Baltic Sea are generally not a 606 reliable proxy for productivity. It is well-known that sedimentary Ba records may be 607 strongly overprinted by remobilization and diagenetic precipitation of barite $\left(\mathrm{BaSO}_{4}\right)$. 608 Particularly in environments with a shallow sulfate-methane transition zone (SMTZ) 609 below which sulfate concentrations drop below saturation with respect to barite, 610 remobilization and diagenetic precipitation of barite occurs (Henkel et al, 2012). This 611 mechanism can also impact the Ba profiles observed in the Fårö Deep and Northern 612 Gotland Basin (Fig. 2). The relatively low salinity of the Baltic Sea, in combination 613 with high rates of methane production in the organic-rich sediments, has led to the 614 formation of a shallow SMTZ ( 20 cmbsf; e.g. Jilbert and Slomp, 2013b). This 615 configuration favors the remobilization of $\mathrm{Ba}$ after accumulation as biogenic barite, 616 partially erasing the original enrichment and smoothing the sedimentary Ba profile. 617 Additionally, barite reprecipitation fronts are often observed close to the SMTZ 618 (Dickens, 2001), fed by an upwards flux of dissolved Ba in the porewaters.

620 The barium profiles at F80 and LL19 show strong enrichments close to the 621 termination of the $\mathrm{HTM}_{\mathrm{HI}}$, but relatively muted enrichments during the rest of the 622 record (Fig. 2). The maximum $\mathrm{Ba}$ values close to the termination of the $\mathrm{HTM}_{\mathrm{HI}}$ 623 correlate with maxima in $\mathrm{C}_{\mathrm{org}}$, $\mathrm{Mo}$ and $\mathrm{U}$ and therefore ostensibly suggest a strong 
624 productivity maximum at this time. However, the anomalously high concentrations 625 lead us to propose that $\mathrm{Ba}$ in this interval was also supplemented by the formation of a 626 barite reprecipitation front. Although the SMTZ at the onset of the $\mathrm{HTM}_{\mathrm{HI}}$ was likely 627 deeper than today due to the higher salinity of the Baltic at this time (Gustafsson and 628 Westman, 2002; Egger et al., 2017), its position must have migrated upwards during 629 the $\mathrm{HTM}_{\mathrm{HI}}$ itself in response to the loading of organic matter. Indeed, the strong Mo 630 enrichments of the $\mathrm{HTM}_{\mathrm{HI}}$ indicate significant levels of free sulfide in pore waters at 631 this time, consistent with a relatively shallow SMTZ. Hence, a barite reprecipitation 632 front likely established at the SMTZ during the $\mathrm{HTM}_{\mathrm{HI}}$ as per the model of Dickens 633 (2001). The $\mathrm{HTM}_{\mathrm{HI}}$ persisted for >3000 yrs (Jilbert and Slomp, 2013a), during which 634 an organic-rich sediment layer of at least 80-100 cm accumulated (Fig. 2). Assuming 635 barite in this layer to be continually remobilized and reprecipitated close to the 636 SMTZ, it follows that the inventory of reprecipitated Ba for the $\mathrm{HTM}_{\mathrm{HI}}$ should be 637 significantly greater than that for the later hypoxic intervals of much shorter duration $638\left(\mathrm{MCA}_{\mathrm{HI}}\right.$ and Modern $\left.\mathrm{HI}\right)$. Hence, no equivalent peak is observed at the termination of 639 the $\mathrm{MCA}_{\mathrm{HI}}$ or in the modern SMTZ. We note that loss of Ba to the water column after 640 barite dissolution in the SMTZ is unlikely during any of the hypoxic intervals, due to 641 the persistent presence of pore water sulfate close to the sediment-water interface 642 (Jilbert and Slomp, 2013b).

As outlined in Section 4.1, Mo and U enrichments are strongly related to 645 bottom water redox conditions. However, both elements also correlate well with $\mathrm{C}_{\text {org }}$, 646 due to the close relationship between productivity and oxygen depletion in the Baltic 647 Sea, and thus serve as indirect proxies for past productivity. Various other trace 648 elements show similarly strong correlations with $\mathrm{C}_{\text {org }}$, which may be more closely 
related to direct input to sediments in association with organic material. These include $\mathrm{Ni}, \mathrm{Tl}$ and particularly $\mathrm{Cu}$ (Fig. 3). Both $\mathrm{Ni}$ and $\mathrm{Cu}$ behave as micronutrients in oxic marine environments and are scavenged in the water column and enriched in sediments through complexation with organic matter (e.g. Calvert and Pedersen, 1993; Piper and Perkins, 2004), while $\mathrm{Cu}$ is also actively scavenged by $\mathrm{Mn}-$ and Feoxides (Fernex et al., 1992). Enrichments in sedimentary $\mathrm{Ni}$ and $\mathrm{Cu}$ have been previously suggested as indicators of higher primary productivity (e.g., Piper and Perkins, 2004; Tribovillard et al., 2006). Our $\mathrm{Cu}$ and $\mathrm{Ni}$ records suggest that this interpretation is valid for the Baltic Sea. Moreover, Tl shows a strong similarity with $\mathrm{Cu}$ and $\mathrm{Ni}$, suggesting that these three elements may be the most suitable trace metals to be applied as proxies for the $\mathrm{C}_{\text {org }}$ flux to the sediments in the Baltic Sea. The similarity of enrichments of $\mathrm{As}$ and $\mathrm{Sb}$ to those of $\mathrm{Fe}$ and $\mathrm{S}$, on the other hand (Fig. 3) show that these elements may be more strongly influenced by the rate of shelf-tobasin Fe shuttling.

\subsection{Trace metals as an indicator of anthropogenic pollution}

Besides the enhanced input of nutrients responsible for the modern eutrophication of the Baltic Sea (Gustafsson et al., 2012; Carstensen et al., 2014a), anthropogenic activity has also led to enhanced input of trace metals (e.g. Kremling and Streu, 2000). These anthropogenically derived trace metals have entered the surface waters of the Baltic Sea via riverine and atmospheric pathways in dissolved and particulate forms (Schneider et al., 2000), resulting in widespread trace metal enrichments in surface sediments of the Baltic Sea (e.g. Borg and Jonsson, 1996; Szefer et al., 1996). Enrichments of $\mathrm{Zn}, \mathrm{Pb}, \mathrm{Sb}, \mathrm{As}, \mathrm{Cd}, \mathrm{Ni}, \mathrm{Tl}$ and $\mathrm{Cu}$ in our data are significantly higher during the Modern $_{\mathrm{HI}}$ than during the $\mathrm{MCA}_{\mathrm{HI}}$ and $\mathrm{HTM}_{\mathrm{HI}}$, 
674 confirming the strong anthropogenic signal in the recent sediments. Although 675 industrialization in the Baltic Sea region was intense from the Second World War 676 onwards, most trace metal enrichments at F80 and LL19 show a rapid onset at the 677 start of the Modern ${ }_{\mathrm{HI}}$, which has been tied to the year 1979 (Lenz et al., 2015b). We 678 attribute this delayed response to a combination of factors. Firstly, because most of 679 these metals are sequestered as authigenic sulfides (e.g. Tribovillard et al., 2006), the 680 hypoxic conditions of the Modern $_{\mathrm{HI}}$, were required before significant accumulation at 681 F80 and LL19 could occur. Secondly, it is likely that these metals initially 682 accumulated in association with Fe oxides in shelf areas, before being transported into 683 the deep basins when Fe shuttling accelerated at the start of the Modern ${ }_{\mathrm{HI}}$ (Lenz et al., 684 2015a). Sedimentary trace metal concentrations remain elevated after the onset of the 685 Modern $_{\mathrm{HI}}$, but the enrichments are generally less extreme. We attribute this to 686 decreasing anthropogenic input (Kremling and Streu, 2000), as well as a decline in the 687 rate of Fe shuttling since the early part of the Modern $_{\mathrm{HI}}$ (Lenz et al., 2015a). The 688 strong effect of recent anthropogenic pollution on the records makes most of these 689 metals unsuitable as quantitative indicators for the intensity of modern hypoxia. A 690 strong anthropogenic overprint does make an element such as $\mathrm{Zn}$, for example, useful 691 as a tool to date recent sediments. Pollution-derived $\mathrm{Pb}$ was already used for this 692 purpose (Zillén et al., 2012; van Helmond et al., 2017).

\section{5. Conclusions}

The trace metal records from the Baltic Sea presented in this study show that

696 Mo and $U$ are strongly correlated with each other and $\mathrm{C}_{\text {org }}$. High concentrations of 697 both trace metals are indicative of frequently euxinic bottom waters during all three 698 hypoxic intervals. High-resolution LA-ICP-MS Mo/U data show that U sequestration 
699

generally leads Mo enrichment, which we attribute to the known redox-dependence of authigenic $\mathrm{U}$ and Mo sequestration. Crossplots of $\mathrm{Mo} / \mathrm{C}_{\mathrm{org}}$ suggest depletion of aqueous Mo concentrations during the $\operatorname{Modern}_{\mathrm{HI}}$. We attribute this to the unprecedented rapid development of widespread hypoxia during the Modern $_{\mathrm{HI}}$ combined with reduced water exchange with the adjacent North Sea. The muted Mn and $\mathrm{Fe}$ oxide particulate shuttle during the last two decades may also contribute to the observed trends in sedimentary Mo by decreasing the supply of Mo to the deep basins of the Baltic Sea. Uranium does not seem to be affected by reservoir and/or shuttling effects. Its maximum concentrations during the Modern $_{\mathrm{HI}}$ suggest that reducing conditions in the Baltic Sea are currently more intense than during the proceeding hypoxic intervals. Rhenium and $\mathrm{V}$ profiles are very different from Mo and $\mathrm{U}$, indicating that their applicability as a quantitative proxy for redox conditions is limited. Our sedimentary records show that Re enrichment commences under relatively mildly reducing conditions, but that $\mathrm{Re}$ is not further enriched under more reducing conditions. Vanadium may experience a significant reservoir effect due to particle reactivity of seawater vanadate in the turbid Baltic Sea, strongly impacting on $\mathrm{V}$ sediment records. Besides $\mathrm{Mo}$ and $\mathrm{U}, \mathrm{Ni}, \mathrm{Tl}$ and particularly $\mathrm{Cu}$ show strong correlation with $\mathrm{C}_{\text {org }}$, suggesting that these are the most reliable trace metals to reconstruct the $\mathrm{C}_{\text {org }}$ flux into the sediments. Barium, in contrast, is largely decoupled from $\mathrm{C}_{\text {org. }}$ We attribute this decoupling to diagenetic remobilization and precipitation of $\mathrm{Ba}$ resulting from a shallow sulfate methane transition zone in the Baltic Sea. Anthropogenic pollution has led to strong enrichments in $\mathrm{Pb}, \mathrm{Zn}, \mathrm{As}, \mathrm{Sb}, \mathrm{Cd}, \mathrm{Ni}, \mathrm{Tl}$ and $\mathrm{Cu}$ during the Modern $_{\mathrm{HI}}$, far exceeding concentrations observed for the previous hypoxic intervals. The profiles for $\mathrm{Pb}$ and $\mathrm{Zn}$ are dominated by such anthropogenic 
sources, making these metals useless as quantitative indicators for (paleo)redox and productivity conditions, while facilitating their use as independent age constraints.

\section{Acknowledgements}

This research was funded by the Netherlands Organisation for Scientific Research (NWO; Vici grant \#865.13.005) and by the European Research Council under the European Community's Seventh Framework Programme (FP7/20072013)/ERC Starting Grant \#278364. This work was carried out under the program of the Netherlands Earth System Science Center (NESSC), financially supported by the Ministry of Education, Culture and Science (OCW). We thank the captain, crew and scientific participants of both cruises with the $R / V$ Aranda, Helen de Waard, Coen Mulder and Arnold van Dijk for analytical assistance and Susanne Bauer and Thomas Algeo for constructive reviews.

\section{References}

Adelson, J.M., Helz, G.R., Miller, C.V., 2001. Reconstructing the rise of recent coastal anoxia; molybdenum in Chesapeake Bay sediments1. Geochim. Cosmochim. Acta 65 (2), 237-252.

Algeo, T.J., Maynard, J.B., 2004. Trace-element behavior and redox facies in core shales of Upper Pennsylvanian Kansas-type cyclothems. Chem. Geol. 206, 289-318.

Algeo, T.J., Lyons, T.W., 2006, Mo-total organic carbon covariation in modern anoxic marine environments: Implications for analysis of paleoredox and 

10.1029/2004PA001112.

Algeo, T.J., Tribovillard, N., 2009. Environmental analysis of paleoceanographic systems based on molybdenum-uranium covariation. Chem. Geol. 268(3), 211-225.

752

Bauer, S., Blomqvist, S., Ingri, J., 2017. Distribution of dissolved and suspended 754 particulate molybdenum, vanadium, and tungsten in the Baltic Sea. Mar. Chem. https://doi.org/10.1016/j.marchem.2017.08.010

756

757 758

759

760

761

762

763

764

765

766

767

768

769

Borg, H., Jonsson, P., 1996. Large-scale metal distribution in Baltic sea sediments. Mar. Pollut. Bull. 32/1, 8-21. 
771 Brumsack, H.J., 2006. The trace metal content of recent organic carbon-rich

772 sediments: Implications for Cretaceous black shale formation. Palaeogeography,

773 Palaeoclimatology, Palaeoecology 232, 344-361.

774

775 Caccia, V.G., Millero, F.J., Palanques, A., 2003. The distribution of trace metals in 776 Florida Bay sediments. Mar. Pollut. Bull. 46(11), 1420-1433.

777

778 Calvert, S.E., Pedersen, T.F., 1993. Geochemistry of Recent oxic and anoxic marine 779 sediments: implications for the geological record. Mar. Geol. 113, 67-88.

780

781 Canfield, D.E., 1994. Factors influencing organic carbon preservation in marine 782 sediments. Chem. Geol. 114(3), 315-329.

783

784 Carstensen, J., Andersen, J.H., Gustafsson, B.G., Conley, D.J., 2014. Deoxygenation 785 of the Baltic Sea during the last century. Proc. Natl. Acad. Sci. U. S. A. 111, 5628786 5633. http://dx.doi.org/10.1073/pnas.1323156111.

787

788 Colodner, D., Sachs, J., Ravizza, G., Turekian, K., Edmond, J., Boyle, E., 1993. The 789 geochemical cycle of rhenium: a reconnaissance. Earth Planet. Sci. Lett. 117, 205790221.

791

792 Conley, D.J., Carstensen, J., Aigars, J., Axe, P., Bonsdorff, E., Eremina, T., Haahti, 793 B.M., Humborg, C., et al., 2011. Hypoxia is increasing in the coastal zone of the 794 Baltic Sea. Environ. Sci. Technol. 45, 6777-6783. 
796 Crusius, J., Calvert, S., Pedersen, T., Sage, D., 1996. Rhenium and molybdenum 797 enrichments in sediments as indicators of oxic, suboxic and sulfidic conditions of 798 deposition. Earth Planet. Sci. Lett. 145(1-4), 65-78.

799

800 Diaz, R.J., Rosenberg, R., 2008. Spreading dead zones and consequences for marine 801 ecosystems. Science 321, 926-929. http://dx.doi.org/10.1126/science.1156401.

802

803 Dickens, G.R., 2001. Sulfate profiles and barium fronts in sediment on the Blake 804 Ridge: present and past methane fluxes through a large gas hydrate reservoir. 805 Geochim. Cosmochim. Acta 65(4), 529-543.

806

807 Dijkstra, N., Slomp, C.P., Behrends, T., 2016. Vivianite is a key sink for phosphorus 808 in sediments of the Landsort Deep, an intermittently anoxic deep basin in the Baltic 809 Sea. Chem. Geol. 438, 58-72.

810

811 Döös, K., Meier, H.E.M., Döscher R., 2004, The Baltic haline conveyor belt or the 812 overturningcirculation and mixingin the Baltic. Ambio 33, 258-262.

813

814 Dymond, J., Suess, E., Lyle, M., 1992. Barium in deep-sea sediment: A geochemical 815 proxy for paleoproductivity. Paleoceanography 7(2), 163-181.

816

817 Egger, M., Hagens, M., Sapart, C.J., Dijkstra, N., van Helmond, N.A.G.M., Mogollón, 818 J.M., Risgaard-Petersen, N., van der Veen, C., Kasten, S., Riedinger, N., Böttcher, 819 M.E., Röckmann, T., Jørgensen, B.B., Slomp, C.P., 2017. Iron oxide reduction in 

http://dx.doi.org/10.1016/j.gca.2017.03.019.

822

823 Emerson, S.R., Huested, S.S., 1991. Ocean anoxia and the concentration of 824 molybdenum and vanadium in seawater. Mar. Chem. 34, 177-196.

825

Fernex, F., Février, G., Benaïm, J., Arnoux, A., 1992. Copper, lead and zinc trapping in Mediterranean deep-sea sediments: probable coprecipitation with manganese and iron. Chem. Geol. 98, 293-308.

829

830 Froelich, P.N., Klinkhammer, G.P., Bender, M.L., Luedtke, N.A., Heath, G.R., 831 Cullen, D., Dauphin, P., Hammond, D., Hartman, B., Maynard, V., 1979. Early 832 oxidation of organic matter in pelagic sediments of the eastern equatorial Atlantic: 833 suboxic diagenesis. Geochim. Cosmochim. Acta 43, 1075-1090.

835 Gustafsson, B.G., Westman, P., 2002. On the causes for salinity variations in the 836 Baltic Sea during the last 8500 years. Paleoceanography 17 (3).

837

838 Gustafsson, B.G., Schenk, F., Blenckner, T., Eilola, K., Meier, H.E.M., Müller839 Karulis, B., Neumann, T., Ruoho-Airola, T., Savchuk, O.P., Zorita, E., 2012. 840 Reconstructing the development of Baltic Sea eutrophication 1850-2006. Ambio 41 841 (6), 534-548. http://dx.doi.org/10.1007/s13280-012-0318-x. 
843 Hardisty, D.S., Riedinger, N., Planavsky, N.J., Asael, D., Andrén, T., Jørgensen, B. 844 B., Lyons, T.W., 2016. A Holocene history of dynamic water column redox 845 conditions in the Landsort Deep, Baltic Sea. Am. J. Sci. 316(8), 713-745.

847 Heiser, U., Neumann, T., Scholten, J., Stuben, D., 2001. Recycling of manganese 848 from anoxic sediments in stagnant basins by seawater inflow: a study of surface 849 sediments from the Gotland Basin, Baltic Sea. Mar. Geol. 177, 151-166.

850

851 Helz, G.R., Miller, C.V., Charnock, J.M., Mosselmans, J.F.W., Patrick, R.A.D., 852 Garner, D.D., Vaughan, D.J., 1996. Mechanism of molybdenum removal from the sea 853 and its concentration in black shales: EXAFS evidence. Geochim. Cosmochim. Acta $85460,3631-3642$.

855

856 Henkel, S., Mogollón, J.M., Nöthen, K., Franke, C., Bogus, K., Robin, E., Bahr, A.,

857 Blumenberg, M., Pape, T., Seifert, R., März, C., de Lange, G.J., Kasten, S., 2012. 858 Diagenetic barium cycling in Black Sea sediments e a case study for anoxic marine 859 environments. Geochim. Cosmochim. Acta 88, 88-105.

860

861 Hennekam, R., Jilbert, T., Mason, P.R., de Lange, G.J., Reichart, G.J., 2015. High862 resolution line-scan analysis of resin-embedded sediments using laser ablation863 inductively coupled plasma-mass spectrometry (LA-ICP-MS). Chem. Geol., 403, 4286451. 

Cenomanian-Turonian black shale deposition at Wunstorf (northern Germany). Cret. Res. 32, 480-494.

869

Huckriede, H., Meischner, D., 1996. Origin and environment of manganese-rich

871 sediments within black-shale basins. Geochim. Cosmochim. Acta 60, 1399-1413.

872

873 Ingri, J.,Widerlund, A., Suteerasak, T., Bauer, S., Elming, S.-Å., 2014. Changes in 874 trace metal sedimentation during freshening of a coastal basin. Mar. Chem. 167, 2-12. 875

876 Ip, C.C.M., Li, X.D., Zhang, G., Wai, O.W.H., Li, Y.S., 2007. Trace metal 877 distribution in sediments of the Pearl River Estuary and the surrounding coastal area, 878 South China. Environ. Pollut. 147, 311-323.

879

880 Jilbert, T., Slomp, C.P., 2013a. Rapid high-amplitude variability in Baltic Sea hypoxia 881 during the Holocene. Geology 41, 1183-1186. http://dx.doi.org/10.1130/G34804.1. 882 883 Jilbert, T., Slomp, C.P., 2013b. Iron and manganese shuttles control the formation of 884 authigenic phosphorus minerals in the euxinic basins of the Baltic Sea. Geochim. 885 Cosmochim. Acta, 107, 155-169.

886

887 Jilbert, T., de Lange, G., Reichart, G.J., 2008. Fluid displacive resin embedding of 888 laminated sediments: preserving trace metals for high-resolution paleoclimate 889 investigations. Limnol. Oceanogr-Meth. 6(1), 16-22. 
891 Jilbert, T., Conley, D.J., Gustafsson, B.G., Funkey, C.P., Slomp, C.P., 2015. Glacio-

892 isostatic control on hypoxia in a high-latitude shelf basin. Geology 43, 427-430.

893 http://dx.doi.org/10.1130/G36454.1.

894 Jokinen, S.A., Virtasalo, J.J., Jilbert, T., Kaiser, J., Dellwig, O., Arz, H.W., Hänninen,

895 J., Arppe, L., Collander, C., Saarinen, T., 2018. A 1500-year multiproxy record of 896 coastal hypoxia from the northern Baltic Sea indicates unprecedented deoxygenation 897 over the 20th century. Biogeosciences, in press.

898 Klinkhammer, G.P., Palmer, M.R., 1991. Uranium in the oceans: where it goes and 899 why. Geochim. Cosmochim. Acta 55, 1799-1806.

900

901 Koide, M., Hodge, V.F., Yany, J., Stallard, M., Goldberg, E., Calhoun, J., Bertine, K., 902 1986. Some comparative marine geochemistries of rhenium, gold, silver and 903 molybdenum. Appl. Geochem. 1, 705-714.

904

905 Kremling, K., Streu, P., 2000. Further evidence for a drastic decline of potentially 906 hazardous trace metals in Baltic Sea surface waters. Mar. Pollut. Bull. 40(8), 674-679. 907

908 Lass, H.U., Matthäus, W., 1996. On temporal wind variations forcing salt water 909 inflows into the Baltic Sea. Tellus 48A, 663-671

910

911 Lenz, C., Jilbert, T., Conley, D.J., Slomp, C.P., 2015a. Hypoxia-driven variations in 912 iron and manganese shuttling in the Baltic Sea over the past 8 kyr. Geochem., 913 Geophys., Geosyst. 16 (10), 3754-3766. 
915 Lenz, C., Jilbert, T., Conley, D.J., Wolthers, M., Slomp, C.P., 2015b. Are recent 916 changes in sediment manganese sequestration in the euxinic basins of the Baltic Sea 917 linked to the expansion of hypoxia? Biogeosciences 12, 4875-4894.

918

919 Liaghati, T., Preda, M., Cox, M., 2004. Heavy metal distribution and controlling 920 factors within coastal plain sediments, Bells Creek catchment, southeast Queensland, 921 Australia. Environ. Int. 29(7), 935-948.

922

923 Matthäus, W., Franck, H., 1992, Characteristics of major Baltic inflows-A statistical 924 analysis, Cont. Shelf Res. 12(12), 1375-1400.

925

926 McArthur, J.M., Algeo, T.J., van de Schootbrugge, B., Li, Q., Howarth, R.J., 2008. 927 Basinal restriction, black shales, Re-Os dating, and the early Toarcian (Jurassic) 928 oceanic anoxic event. Paleoceanography 23, PA4217. doi:10.1029/2008PA001607. 929

930 McLennan, S.M., 2001. Relationships between the trace element composition of 931 sedimentary rocks and upper continental crust. Geochem., Geophys., Geosyst. $9322(4)$.

934 McManus, J., Berelson,W.M., Klinkhammer, G.P., Johnson, K.S., Coale, K.H., 935 Anderson, R.F., Kumar, N., Burdige, D.J., Hammond, D.E., Brumsack, H.J., 936 McCorkle, D.C., Rushdi, A., 1998. Geochemistry of barium in marine sediments: 937 Implications for its use as a paleoproxy. Geochim. Cosmochim. Acta 62, 3453-3473. 938 
939

940

941

942

943

944

945

946

947

948

949

950

951

952

953

954

955

956

957

958

959

960 Nijenhuis, I.A., Bosch, H.J., Sinninghe Damsté, J.S., Brumsack, H.J., De Lange, G. J.,

961 1999. Organic matter and trace element rich sapropels and black shales: a

962 geochemical comparison. Earth Planet. Sci. Lett. 169(3), 277-290.

Morford, J.L., Emerson, S., 1999. The geochemistry of redox sensitive trace metals in sediments. Geochim. Cosmochim. Acta 63(11), 1735-1750.

Morford, J.L., Emerson, S.R., Breckel, E.J., Kim, S.H., 2005. Diagenesis of oxyanions (V, U, Re, and Mo) in pore waters and sediments from a continental margin. Geochim. Cosmochim. Acta 69, 5021-5032.

Morford, J.L., Martin, W.R., Carney, C.M., 2012. Rhenium geochemical cycling: insights from continental margins. Chem. Geol. 324-325, 73-86.

Morse, J.W., Luther, G.W., 1999. Chemical influences on trace metal-sulfide interactions in anoxic sediments. Geochim. Cosmochim. Acta 63(19), 3373-3378.

Nägler, T.F., Neubert, N., Böttcher, M.E., Dellwig, O., Schnetger, B., 2011. Molybdenum isotope fractionation in pelagic euxinia: evidence from the modern Black and Baltic seas. Chem. Geol. 289, 1-11. 
964 Noordmann, J., Weyer, S., Montoya-Pino, C., Dellwig, O., Neubert, N., Eckert, S., 965 Paetzel, M., Böttcher, M.E., 2015. Uranium and molybdenum isotope systematics in 966 modern euxinic basins: case studies from the central Baltic Sea and the Kyllaren fjord 967 (Norway). Chem. Geol. 396, 182-195.

968

969 Nriagu, J.O., Pacyna, J.M., 1988. Quantitative assessment of worldwide 970 contamination of air, water and soils by trace metals. Nature 333, 134-139.

971

972 O'Connor, A.E., Luek, J.L., McIntosh, H., Beck, A.J., 2015. Geochemistry of redox973 sensitive trace elements in a shallow subterranean estuary. Mar. Chem. 172, 70-81.

974

975 Olson, L., Quinn, K.A., Siebecker, M.G., Luther, G.W., Hastings, D., Morford, J.L., 976 2017. Trace metal diagenesis in sulfidic sediments: Insights from Chesapeake Bay. 977 Chem. Geol. 452, 47-59.

978

979 Papadomanolaki, N.M., Dijkstra, N., Van Helmond, N.A.G.M., Hagens, M., 980 Bauersachs, T., Kotthoff, U., Sangiorgi, F., Slomp, C.P., 2018. Controls on the onset 981 and termination of past hypoxia in the Baltic Sea. Palaeogeogr., Palaeocl. 490, 347982354.

983

984 Pedersen, T.F., Calvert, S.E., 1990. Anoxia vs. productivity: what controls the 985 formation of organic-carbon-rich sediments and sedimentary Rocks? (1). Aapg 986 Bull.74(4), 454-466. 
Piper, D.Z., Perkins, R.B., 2004. A modern vs. Permian black shale-the hydrography, primary productivity, and water-column chemistry of deposition. Chem. Geol. 206(3-4), 177-197.

Plewa, K., Meggers, H., Kasten, S., 2012. Barium in sediments off northwest Africa: a 993 tracer for paleoproductivity or meltwater events? Paleoceanography 21. http://dx.doi.org/10.1029/2005PA001136.

995

Prange, A., Kremling, K., 1985. Distribution of dissolved molybdenum, uranium and 997 vanadium in Baltic Sea waters. Mar. Chem. 16(3), 259-274.

998

999 Rinna, J., Warning, B., Meyers, P.A., Brumsack, H.J., Rullkötter, J., 2002. Combined 1000 organic and inorganic geochemical reconstruction of paleodepositional conditions of a 1001 Pliocene sapropel from the eastern Mediterranean Sea. Geochim. Cosmochim. Acta 1002 66(11), 1969-1986.

1003

1004 Schaller, T., Morford, J., Emerson, S., Feely, R., 2000. Oxyanions in metalliferous 1005 sediments: tracers for paleoseawater metal concentrations? Geochim. Cosmoch. Acta $1006 \quad 63(13), 2243-2254$.

1008 Schinke, H., Matthäus, W., 1998. On the causes of major Baltic inflows — an analysis 1009 of long time series. Cont. Shelf Res. 18, 67-97. 
1011 Schneider, B., Ceburnis, D., Marks, R., Munthe, J., Petersen, G., Sofiev, M., 2000.

1012 Atmospheric $\mathrm{Pb}$ and $\mathrm{Cd}$ input into the Baltic Sea: a new estimate based on 1013 measurements. Mar. Chem. 71, 297 - 307.

1014

1015 Schoepfer, S.D., Shen, J., Wei, H., Tyson, R.V., Ingall, E., Algeo, T.J., 2015. Total 1016 organic carbon, organic phosphorus, and biogenic barium fluxes as proxies for 1017 paleomarine productivity. Earth-Sci. Rev. 149, 23-52.

1018

1019 Scott, C., Lyons, T.W., 2012. Contrasting molybdenum cycling and isotopic 1020 properties in euxinic versus non-euxinic sediments and sedimentary rocks: refining 1021 the paleoproxies. Chem. Geol. 324-325, 19-27.

1022

1023 Shaw, T.J., Gieskes, J.M., Jahnke, R.A., 1990. Early diagenesis in differing 1024 depositional environments: the response of transition metals in pore water. Geochim. 1025 Cosmochim. Acta 54(5), 1233-1246.

1026

1027 Sulu-Gambari, F., Roepert, A., Jilbert, T., Hagens, M., Meysman, F.J., Slomp, C.P., 1028 2017. Molybdenum dynamics in sediments of a seasonally-hypoxic coastal marine 1029 basin. Chem. Geol. 466, 627-640.

1030

1031 Szefer, P., Szefer, K., Glasby, G.P., Pempkowiak, J., Kaliszan, R., 1996. Heavy metal 1032 pollution in surficial sediments from the southern Baltic Sea off Poland. J. Environ. 1033 Sci. Heal. A 31 (10), 2723-2754. 
1035 Tribovillard, N., Algeo, T.J., Lyons, T., Riboulleau, A., 2006. Trace metals as 1036 paleoredox and paleoproductivity proxies: an update. Chem. Geol. 232(1), 12-32.

1038 Tribovillard, N., Algeo, T.J., Baudin, F., Riboulleau, A., 2012. Analysis of marine 1039 environmental conditions based onmolybdenum-uranium covariation-Applications 1040 to Mesozoic paleoceanography. Chem. Geol. 324, 46-58.

1041

1042 Turekian, K.K., 1977. The fate of metals in the oceans. Geochim. Cosmochim. Acta 1043 41(8), 1139-1144.

1044

1045 van Helmond, N.A.G.M., Ruvalcaba Baroni, I., Sluijs, A., Sinninghe Damsté, J.S., 1046 Slomp, C.P., 2014. Spatial extent and degree of oxygen depletion in the deep proto1047 North Atlantic Basin during Oceanic Anoxic Event 2. Geochem., Geophys., Geosyst. $104815(11), 4254-4266$.

1049

1050 van Helmond, N.A.G.M., Quintana Krupinski, N.B., Lougheed, B.C., Obrochta, S.P., 1051 Andrén, T., Slomp, C.P., 2017. Seasonal hypoxia was a natural feature of the coastal 1052 zone in the Little Belt, Denmark, during the past 8 ka. Mar. Geol. 387, 45-57.

1053

1054 Von Breymann, M.T., Emeis, K.-C., Suess, E., 1992. Water depth and diagenetic 1055 constraints on the use of barium as a palaeoproductivity indicator. Geol. Soc. Lond. 1056 Spec. Publ. 64, 273-284. 
1058 Wanty, R.B., Goldhaber, R., 1992. Thermodynamics and kinetics of reactions 1059 involving vanadium in natural systems: accumulation of vanadium in sedimentary 1060 rock. Geochim. Cosmochim. Acta 56, 171-183.

1061

1062 Wehrli, B., Stumm, W., 1989. Vanadyl in natural waters: adsorption and hydrolysis 1063 promote oxygenation. Geochim. Cosmochim. Acta 53, 69-77.

1064

1065 Windom, H.L., Schropp, S.J., Calder, F.D., Ryan, J.D., Smith Jr., R.G., Burney, L.C., 1066 Lewis, F.G., Rawlinson, C.H., 1989. Natural trace metal concentrations in estuarine 1067 and coastal marine sediments of the southeastern United States. Environ. Sci. 1068 Technol. 23, 314-320.

1069

Zheng, Y., Anderson, R.F., van Geen, A., Fleisher, M.Q., 2002. Preservation of 1071 nonlithogenic particulate uranium in marine sediments. Geochim. Cosmochim. Acta $107266,3085-3092$.

1073

1074 Zillén, L., Conley, D.J., Andrén, T., Andrén, E., Björck, S., 2008. Past occurrences of 1075 hypoxia in the Baltic Sea and the role of climate variability, environmental change 1076 and human impact. Earth Sci. Rev. 91, 77-92. http://dx.doi.org/10.1016/j.earscirev. 10772008.10 .001$.

1078

1079 Zillén, L., Lenz, C., Jilbert, T., 2012. Stable lead (Pb) isotopes and concentrations - A 1080 useful independent dating tool for Baltic Sea sediments. Quat. Geochronol. 8, 41-45. 1081 1082 Table captions 
1084 Table 1. Average (avg.) and maximum (max.) values for $\mathrm{C}_{\mathrm{org}}, \mathrm{Mo}, \mathrm{U}, \mathrm{Re}, \mathrm{V}, \mathrm{Ba}, \mathrm{Zn}$, $1085 \mathrm{~Pb}, \mathrm{Sb}, \mathrm{As}, \mathrm{Cd}, \mathrm{Ni}, \mathrm{Tl}, \mathrm{Cu}, \mathrm{Fe}, \mathrm{S}$ for the three hypoxic intervals and background at site 1086 F80.

1087

1088

* Modern ${ }_{\mathrm{HI}}$ including the not yet compacted and degraded surface sediments rich in 1089 fresh organic matter the so-called "fluffy" layer between brackets.

1090

1091 Table 2. Average (avg.) and maximum (max.) values for $\mathrm{C}_{\mathrm{org}}$, Mo, U, Re, V, Ba, Zn, $1092 \mathrm{~Pb}, \mathrm{Sb}, \mathrm{As}, \mathrm{Cd}, \mathrm{Ni}, \mathrm{Tl}, \mathrm{Cu}, \mathrm{Fe}, \mathrm{S}$ for the three hypoxic intervals and background at site 1093 LL19.

1094

1095

* Modern $_{\mathrm{HI}}$ including the not yet compacted and degraded surface sediments rich in 1096 fresh organic matter the so-called "fluffy" layer between brackets. 


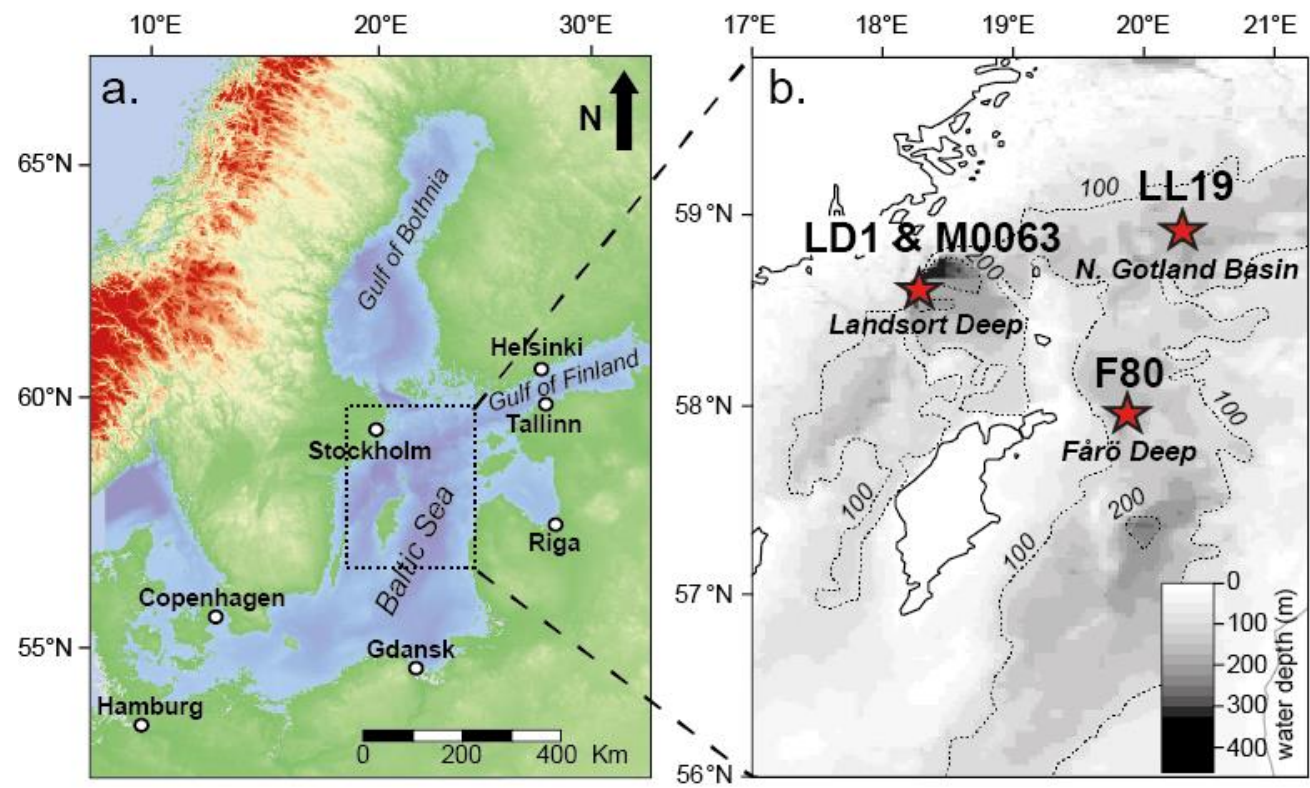

1110 Figure 1. Bathymetric map of the Baltic Sea generated at www.helcom.fi (a).

1111 Detailed bathymetric map of the central part of the Baltic Sea, with our study sites

1112 F80 and LL19 and the sites brought forward in the discussion, LD1 \& M0063 (Lenz

1113 et al., 2015b; Dijkstra et al., 2016; Hardisty et al., 2016), marked by a red star (b).

1114 Map modified from Jilbert and Slomp (2013a). 
a.

F80 - Fårö Deep - 191 mbs

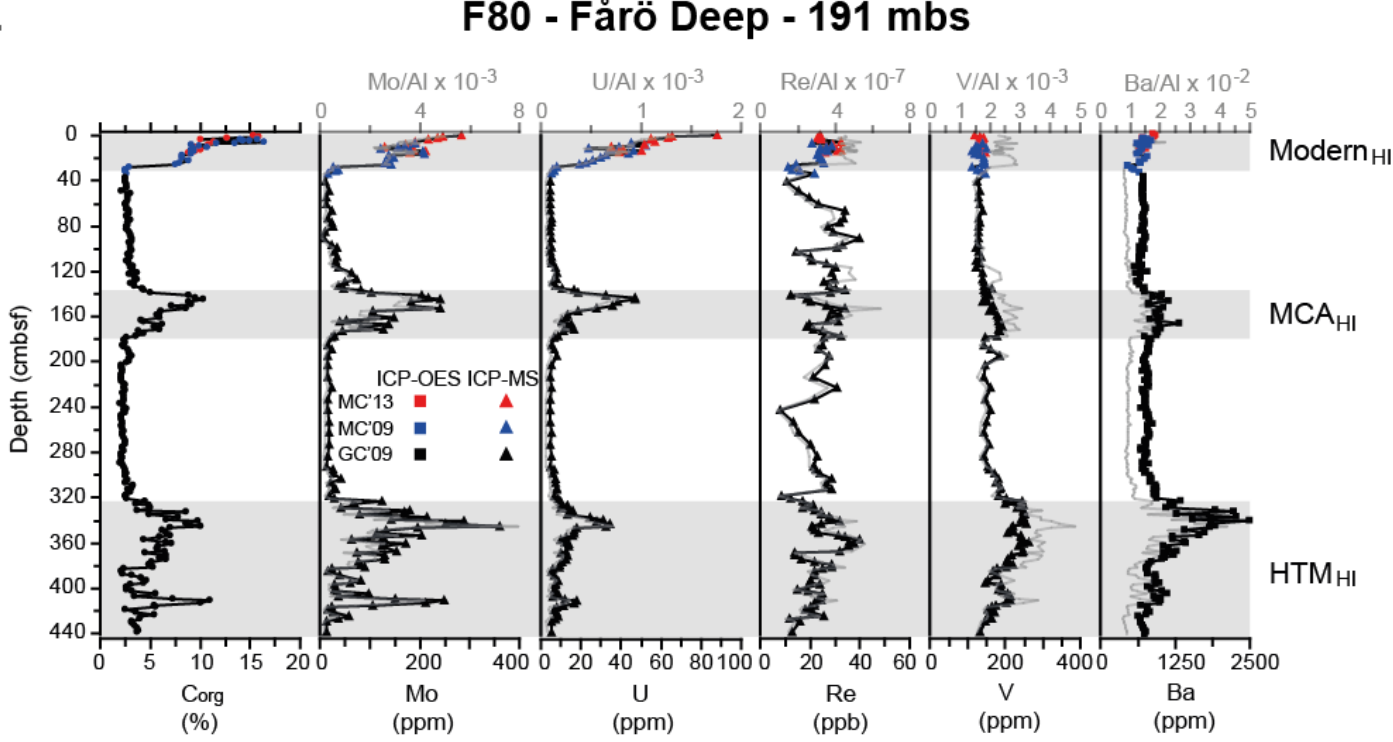

b.

\section{LL19 - N. Gotland Basin - 169 mbs}

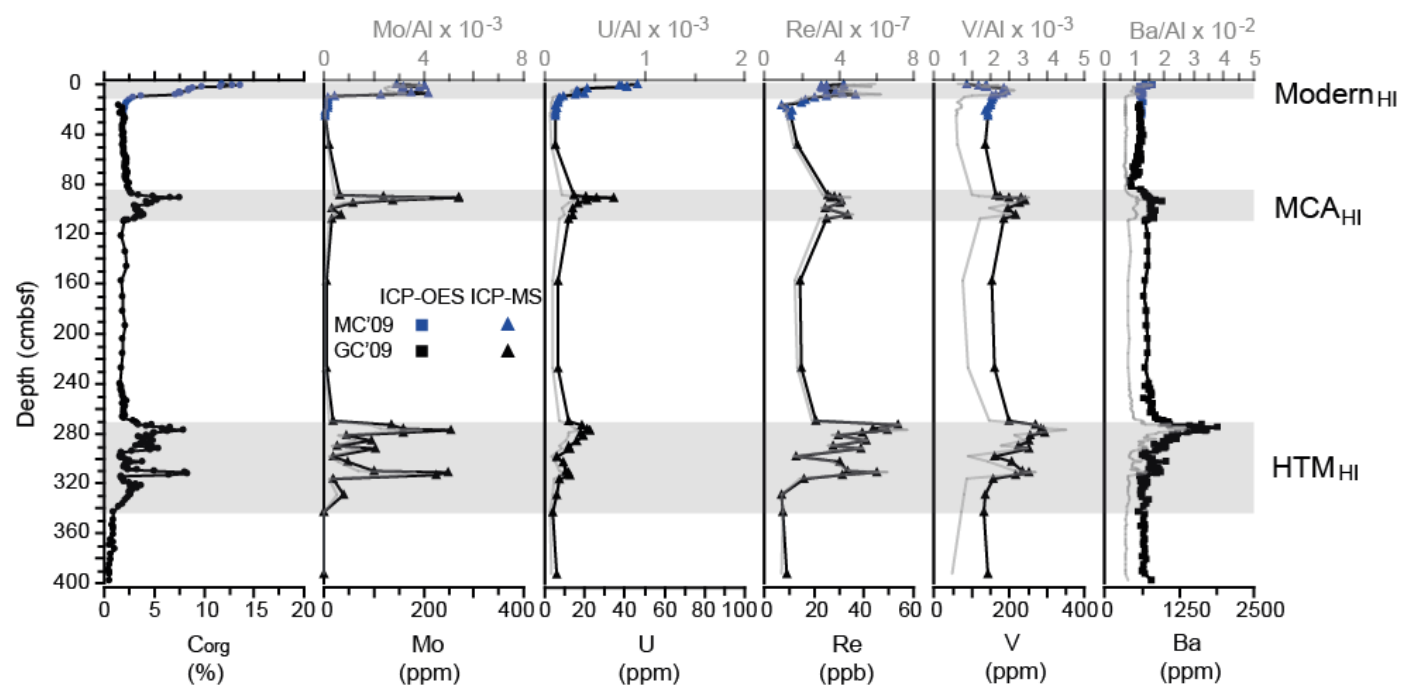

1116 Figure 2. Profiles of $\mathrm{C}_{\mathrm{org}}$, Mo, Mo/Al, U, U/Al, Re, Re/Al, V, V/Al, Ba and Ba/Al,

1117 for F80 (a.) and LL19 (b.) plotted against depth. Grey bars indicate the three hypoxic

1118 intervals in the Baltic Sea: the modern hypoxic interval $\left(\operatorname{Modern}_{\mathrm{HI}}\right)$, the hypoxic

1119 interval during the Medieval Climate Anomaly $\left(\mathrm{MCA}_{\mathrm{HI}}\right)$ and the hypoxic interval

1120 during the Holocene Thermal Maximum $\left(\mathrm{HTM}_{\mathrm{HI}}\right)$. The data for the multicores

1121 collected in 2009 (MC'09) are represented by blue symbols, while the data for the

1122 GEMAX core collected in 2013 (MC'13) are represented by red symbols. The data

1123 for gravity cores collected in 2009 (GC'09) are represented by black symbols. 
a.

F80 - Fårö Deep - 191 mbs

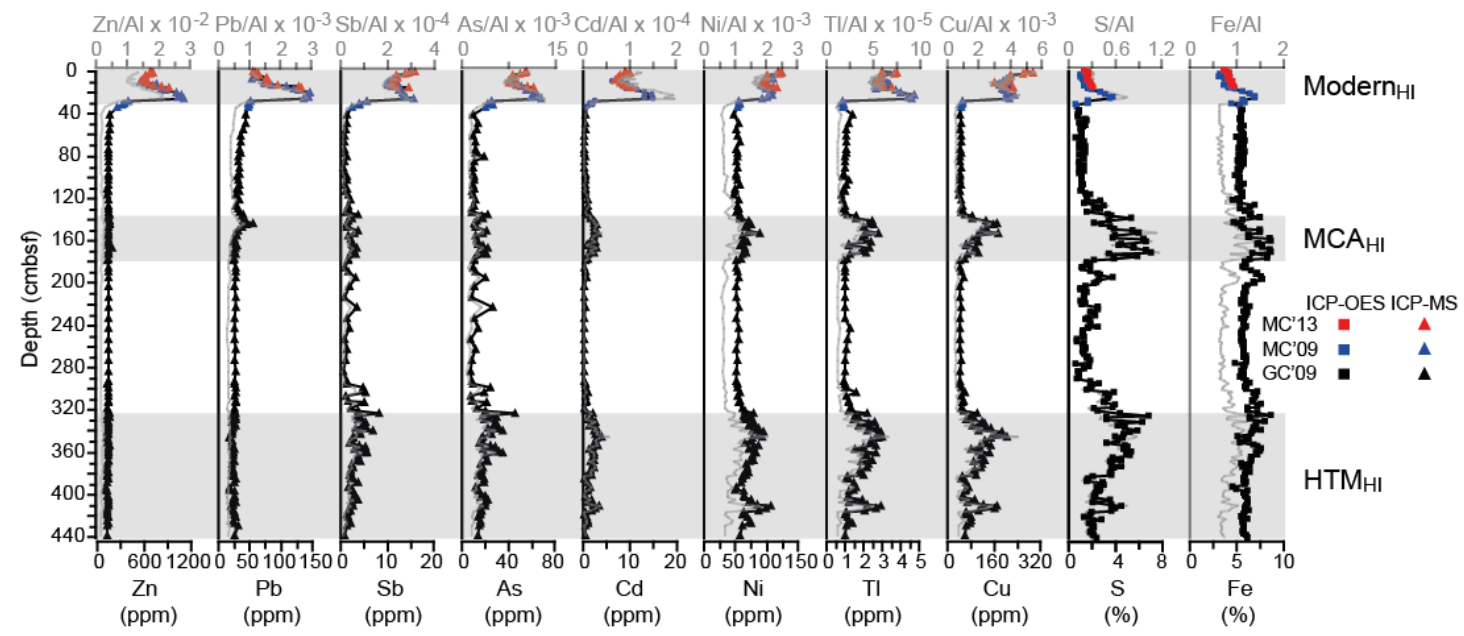

b.

LL19 - N. Gotland Basin - 169 mbs

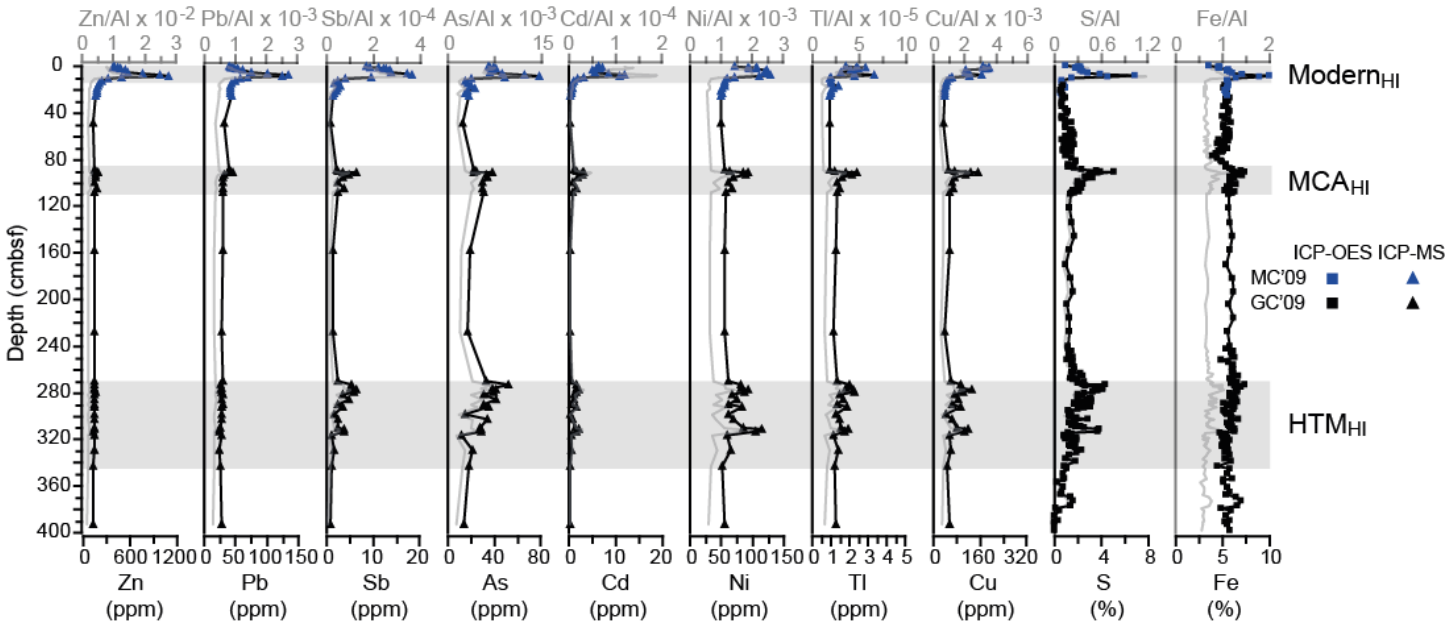

Figure 3. Profiles of $\mathrm{Zn}, \mathrm{Zn} / \mathrm{Al}, \mathrm{Pb}, \mathrm{Pb} / \mathrm{Al}, \mathrm{Sb}, \mathrm{Sb} / \mathrm{Al}, \mathrm{As}, \mathrm{As} / \mathrm{Al}, \mathrm{Cd}, \mathrm{Cd} / \mathrm{Al}, \mathrm{Ni}$, against depth. Grey bars indicate the three hypoxic intervals in the Baltic Sea: the modern hypoxic interval $\left(\operatorname{Modern}_{\mathrm{HI}}\right)$, the hypoxic interval during the Medieval

1129 Climate Anomaly $\left(\mathrm{MCA}_{\mathrm{HI}}\right)$ and the hypoxic interval during the Holocene Thermal 1130 Maximum $\left(\mathrm{HTM}_{\mathrm{HI}}\right)$. The data for multicores collected in 2009 (MC'09) are 1131 represented by blue symbols, while those for the GEMAX core collected in 2013 1132 (MC'13) are represented by red symbols. The data for gravity cores collected in 2009 1133 (GC'09) are represented by black symbols. 

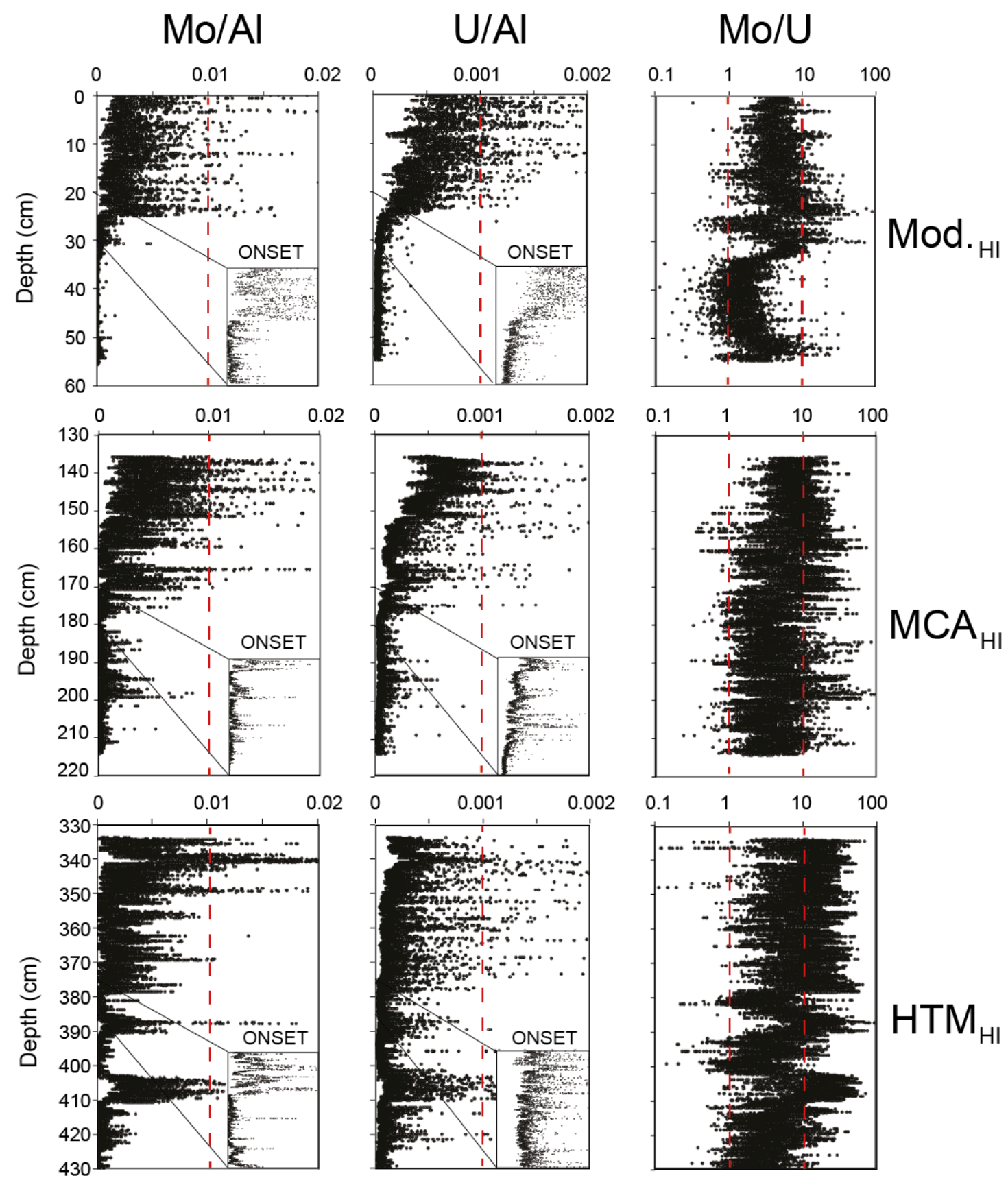

Figure 4. High-resolution, Laser Ablation-Inductively Coupled Plasma-Mass

1137 Spectrometry (LA-ICP-MS) Mo/Al, U/Al and Mo/U profiles for the three hypoxic

1138 intervals in the Baltic Sea for F80: the modern hypoxic interval $\left(\operatorname{Modern}_{\mathrm{HI}}\right)$, the

1139 hypoxic interval during the Medieval Climate Anomaly $\left(\mathrm{MCA}_{\mathrm{HI}}\right)$ and the hypoxic 1140 interval during the Holocene Thermal Maximum $\left(\mathrm{HTM}_{\mathrm{HI}}\right)$. 

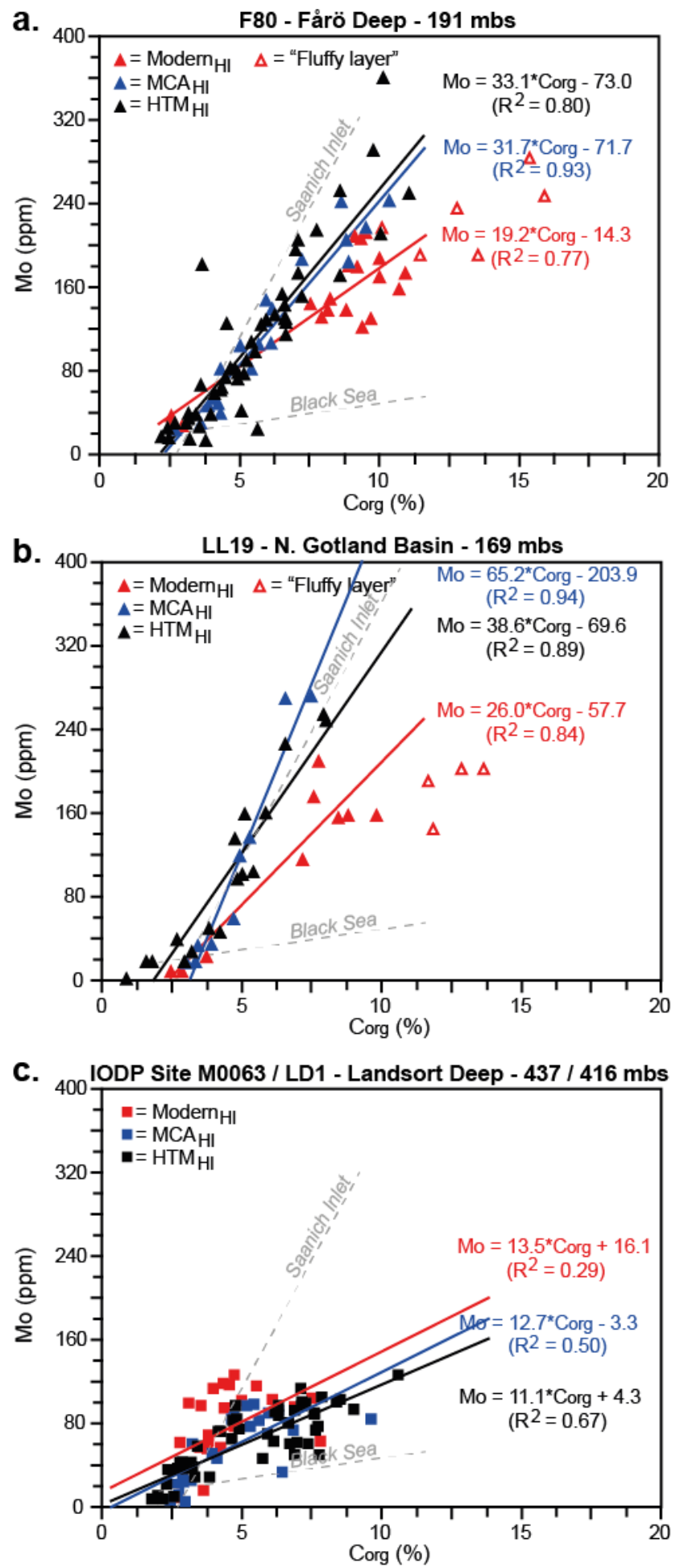

Figure 5. Cross-plots of sedimentary Mo versus $C_{\text {org }}$ for F80 (a), LL19 (b) and the 1145 Landsort Deep (IODP exp. 347 Site M0063; Dijksta et al., $2016-\mathrm{MCA}_{\mathrm{HI}}$ and HTM $\mathrm{HI}_{\mathrm{I}}$ 1146 and LD1; Lenz et al., 2015b - Modern ${ }_{\mathrm{HI}}$ ) for the three hypoxic intervals in the Baltic 1147 Sea: the modern hypoxic interval Modern $_{\mathrm{HI}}$; red), the hypoxic interval during the 1148 Medieval Climate Anomaly $\left(\mathrm{MCA}_{\mathrm{HI}}\right.$; blue) and the hypoxic interval during the 
1150 for sedimentary Mo versus $\mathrm{C}_{\text {org }}$. For the calculation of the regression slopes samples

1151 from the surface "fluffy layer" were excluded. The dashed lines show the regression 1152 slopes for sedimentary Mo versus $\mathrm{C}_{\text {org }}$ for the weakly restricted Saanich Inlet and the 1153 severely restricted Black Sea (Algeo and Lyons, 2006).

1154

a. $\quad$ F80 - Fårö Deep - $191 \mathrm{mbs}$

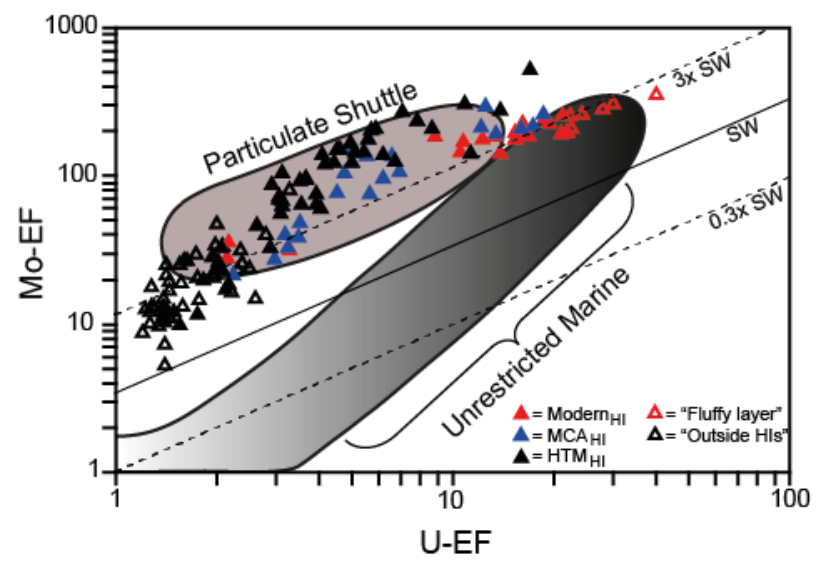

b. LL19 - N. Gotland Basin - 169 mbs

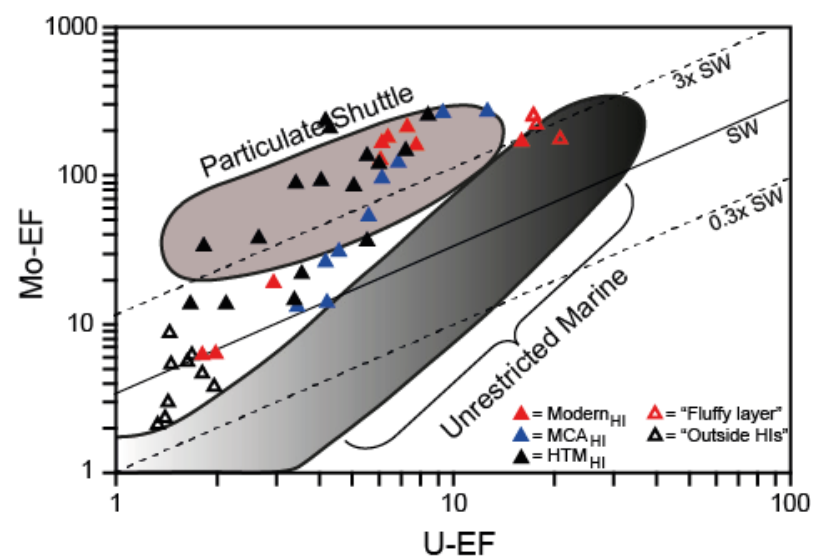

1156 Figure 6. Cross-plots of the enrichment factors (EF), following Algeo and 1157 Tribovillard (2009) and Tribovillard et al. (2012), of Mo and U for F80 (a) and LL19 1158 (b) plotted on a logarithmic scale. The shaded areas represent the types of 1159 environment in which sediments with such composition are deposited, i.e. a system 1160 characterized by an active particulate shuttle like the Cariaco Basin or an unrestricted 
1161 marine system such as the eastern tropical Pacific (Algeo and Tribovillard, 2009; 1162 Tribovillard et al., 2012). The diagonal lines represent multiples of the Mo:U ratio in 1163 present-day seawater. Molar ratios of $\sim 7.5$ for the Pacific and $\sim 7.9$ for the Atlantic 1164 have been converted to an average weight ratio of 3.1 for the purpose of comparison 1165 with sediment Mo:U weight ratios (cf. Tribovillard et al., 2012). 